\title{
Accounting Standards and Financial Market Stability: An Experimental Examination
}

\author{
Shengle Lin \\ San Francisco State University \\ Glenn Pfeiffer \\ Chapman University \\ David Porter \\ Chapman University
}

Latest Version: March $5^{\text {th }}, 2014$

\begin{abstract}
We examine the effect on asset mispricing of different accounting methods in an experimental asset market characterized by bubbles and crashes. In particular, we study three alternative asset value reporting treatments: (1) Fair Value (also known as Mark-to-Market - M2M), (2) Historical Cost (HC) and (3) Marked to Fundamental Value (M2F). In addition, each of these treatments is replicated in two different financial leverage conditions. In the first condition (No Loan) traders must purchase assets from their available cash balances without the option of borrowing. In the second condition, (Loan), traders are given the option of taking out loans based on their balance sheet to finance asset purchases. In the No Loan condition, we find that reporting accounting values alone to subjects in a balance sheet format does not have a significant effect on mispricing for any of our alternative accounting method treatments. In the Loan conditions, however, the $\mathrm{M} 2 \mathrm{~F}$ and $\mathrm{M} 2 \mathrm{M}$ accounting methods exacerbate asset mispricing, yet the two differ in leverage dynamics. M2F markets are completely immune to defaults, while $\mathrm{M} 2 \mathrm{M}$ markets experience the most frequent as well as most severe defaults.
\end{abstract}




\section{Introduction}

The use of fair value accounting by banks and other financial institutions has been posited to be a factor that contributed to the financial crisis in $2008 .^{1}$ Fair value accounting, which is sometimes referred to as "mark-to-market," is the practice of increasing or decreasing the reported value of assets in a firm's balance sheet to reflect changes in the market prices of those assets. As a result, the balance sheet reports the current value of those assets rather than the outdated (historical) cost at which those assets were acquired. Since 1992, financial institutions have been required to use fair value accounting to report some of the financial assets presented in bank balance sheets. Advocates of fair value accounting argue that these reported values provide a more accurate measure of the financial health and viability of financial institutions and a better measure of capital adequacy, particularly for regulatory purposes (Morris and Sellon, 1991; Barth, 1994; Carey, 1995; Barth, Landsman and Wahlen, 1995). In addition, reported asset values based on fair value are assumed to be more relevant for most economic decisions than historical cost valuations. This value relevance is supported by empirical data (Barth, 1994; Eccher, Ramesh, and Thiagarajan, 1996; Cornett, Rezaee, and Tehranian, 1996). This virtue, however, depends on the reliability of the fair value measures. Reliability refers to the extent to which the fair value of an asset reflects its underlying fundamental economic value.

Critics have argued that fair value accounting increases the volatility of reported earnings and capital of financial institutions, causing unintended consequences for the management of capital reserves. Market volatility can force firms to engage in short-term modifications of their investment positions in order to meet capital requirements imposed by bank regulators. The bursting of the real estate bubble in 2007 and the subsequent financial crisis in 2008 is a prime example. During the preceding decade, steadily increasing home prices led to increased aggregate investment in real estate. When the bubble burst, the precipitous drop in real estate prices led to increased foreclosures and a corresponding decline in the value of bank assets. The decline in asset values immediately hit balance sheets because of fair value accounting. Some banks were forced to sell assets at "fire-sale" prices in order to maintain liquidity and regulatory capital. The sell-off of assets further depressed market prices which, in turn, depressed the asset values of other banks, creating a contagion effect.

\footnotetext{
${ }^{1}$ Wesbury (2009) argues that “... market-to-market accounting was in place during the Great Depression. Milton Friedman blames it for causing a majority of bank failures in the 1930s. It was suspended in $1938 \ldots$ The U.S. economy did just fine between 1938 and 2007. During those 69 years, there were no panics or depressions. But when the Financial Accounting Standards Board (FASB) - the rule-setting body for U.S. accounting standards - put a stringent fair value accounting rule (Rule 157) back into place in November 2007, all hell broke loose. This is not a coincidence. Fair value accounting is a disaster. "
} 
Perhaps it is not surprising that most of the complaints about fair value accounting are voiced during periods of market distress. However, in order to avoid repeating past mistakes, it is important that we understand what factors caused the bubble in the first place. That is, did fair value accounting contribute to distortions in asset values that were later unwound during the financial crisis? In this study, we examine the effect of three different accounting regimes on asset market prices in an experimental market setting that has been shown to be prone to a pattern of bubble and crash. Specifically, we examine how balance sheets that report asset values using either historical cost $(\mathrm{HC})$, fair value $(\mathrm{M} 2 \mathrm{M})$ or fundamental value $(\mathrm{M} 2 \mathrm{~F})^{2}$ affect the size and duration of asset market bubbles.

We test these three accounting alternatives in laboratory asset market modeled by Smith, Suchanek and Williams (1988). The market has been used widely in the literature and is prone to price bubbles followed by crashes. Various explanations have been proposed for why price bubbles arise in a market with common knowledge in the underlying asset value ${ }^{3}$. The purpose of our study is to examine different accounting methods in a market environment that provides stress tests on the robustness of these accounting methods of asset valuation.

In theory, the accounting method used to report an asset's value should not have any impact on the amount a buyer would be willing to pay to acquire that asset. Nor should the reported value affect a seller's reservation price for the same asset. Hence, we do not expect that asset value reporting, alone, will have much effect on the market prices of assets. However, when the reported value of an asset is used to determine potential debt capacity for a borrower, the accounting valuation may have an effect on the amount borrowed and subsequently invested. If market prices are inflated, as is the case in a bubble, reported asset values would also be

\footnotetext{
${ }^{2}$ This method is akin to a "mark-to-model," where the asset value is set equal to the value determined by an accepted valuation model using parameter values obtained from public sources. An example is the use of a discounted cash flow model with a quoted discount rate to value a bond. At best, this method uses market inputs as parameter values, so the same caveats regarding reliability apply as with mark-to-market values. For our purposes, the fundamental value is defined as the undiscounted expected dividend paid on an asset. As such, it is unambiguously determined independent of market prices. However, unlike the other two accounting methods of which the numbers can be obtained from either current prices or past prices, fundamental values are usually costly to obtain.

3 These factors include liquidity, experience, transparency, novelty of environment and speculation (Caginalp, Porter, and Smith, 2001; Dufwenberg, Lindqvist, and Moore, 2005, Hussam, Porter, and Smith, 2008; Lei, Noussair, and Plott, 2001) Lei, Noussair, and Plott (2001) find that bubbles do not disappear in markets in which speculation is not possible. Kirchler, Huber, and Stöckl (2012) argue that bubbles are related to the declining fundamental value because traders do not fully comprehend the process. Noussair and Ruffieux (2001) find bubbles in markets with constant fundamental values. For a survey of bubbles in experimental assets see Palan (2014).
} 
overstated under fair value accounting. This could potentially result in higher debt balances and greater market liquidity. When the bubble bursts and asset market prices fall, accounting values are adjusted downward and outstanding debt may no longer be adequately backed by the assets, creating a potential for default. To address the effect of reported asset values on debt capacity and market liquidity, we evaluate two financial leverage conditions for each of the accounting alternatives examined. In one of these conditions, subjects were required to purchase assets from available cash balances without the option of borrowing. In the other condition, subjects are allowed to borrow funds secured by the accounting value of the assets they own. The potential effect of this additional debt capacity is to increase liquidity in the market. The amount of debt available depends on the reported value of the assets and, consequently, distortions in asset values based on the accounting method used can have an impact on market liquidity. ${ }^{4}$

Our results suggest that the alternative reporting methods have little direct impact on the magnitude or the duration of asset market bubbles. However, when reported asset values are used to determine debt capacity, we find that traders borrow more in a fair value reporting environment and this increased liquidity leads to larger price bubbles of greater duration. Furthermore, loan defaults were more likely in markets where assets were reported using fair value accounting than in markets using historical cost or fundamental value.

We find that the defaults are related to the traders' leverage levels and leverage dynamics can explain why the three accounting alternatives perform differently. In M2F, loans are closely anchored on the fundamental value regardless of the market prices; as fundamental values decline over time, traders are de-leveraged automatically. Throughout all M2F markets, no default is observed though the overall amount of debt is initially comparable to that of M2M. In $\mathrm{M} 2 \mathrm{M}$, financial leverage increases over time as prices appreciate and move in the opposite direction of asset fundamentals. Those traders with high leverage positions are the most likely to be unable to raise sufficient capital to pay back loans at maturity. In these experimental asset markets, prices tend to begin below fundamental value and then race above fundamental value until they run out of steam and crash. With this type of price pattern, the HC treatment provides for a lower debt capacity that eases the unwinding of individual loan positions.

We also find that those subjects who default have the largest discrepancy between their true debt levels (defined as the ratio of debt to total assets at fundamental value) and reported debt

\footnotetext{
${ }^{4}$ In our experiments we chose not to have subjects represent lending institutions, instead we just used a specific rule to allow loans to be taken based on balance sheet values. We did this to keep the lending rule fixed and constant so we could examine the effect of the accounting rules on asset prices with less confounds.
} 
levels (the ratio of debt to reported asset values). M2M has a larger discrepancy than $\mathrm{HC}$, that is, M2M understates reported debt levels the most.

The remainder of the paper is organized as follows. Section 2 describes our experimental market design and loan mechanism. Section 3 reports on the bubble characteristics, loan adoptions and defaults, followed by an examination of the leveraging process across treatments. The last section concludes. 


\section{Experimental Design}

We employ a $3 \times 2$ experimental design using three different asset reporting treatments and two financial leverage conditions. The alternative accounting treatments include (1) Fair Value (also known as Mark-to-Market -- M2M)), (2) Historical Cost (HC) and (3) Mark-to-Fundamental Value (M2F). Each of these accounting treatments represents an alternative asset valuation framework. In addition, each of these treatments is replicated in two different financial leverage conditions. In the first condition (No Loans $-\mathrm{NL}$ ) traders must purchase assets from their available cash balances without the option of borrowing. In the second condition, (Loans - L), traders are given the option of taking out loans to finance asset purchases. This design structure is summarized in Table 1.

\subsection{Asset Market}

Our market structure follows the type of asset market initiated by Smith, Suchanek and Williams (1988). This design has been used in hundreds of studies and bubbles/crashes are frequent in these markets. Hence, the design is suitable for introducing volatility into the market and offers stress tests for alternative asset value measurement methods.

Our economic environment consisted of a risky asset (a Share) that paid a series of dividends with common knowledge on the distribution. The asset was traded in a double auction market during a trading period. All prices, dividends, and earnings were denominated in US cents (c), and paid out at a ratio of $1: 1$ at the end of the experiment.

Each market is divided into 15 periods. Each share pays a random dividend at the end of each period. The dividend is set at either $0 \dot{C}, 8 \zeta, 28 c$ or $60 c$ per period per share. Each of these four amounts is equally likely to occur and dividend draws in different periods are independent from each other. Hence, each share is expected to earn the owner an average dividend of 24c per period. Over a lifetime of 15 periods, a share is expected to generate a total dividend payout of 360c. Dividend earnings are realized at the end of each period and are added to the holder's cash account immediately. Each trader's cash and share holdings carry over to the next period. As periods continue, the expected value of the remaining share dividends is estimated to decline by $24 C$ each period. In period 15 , there would be one last dividend payment. After that, all shares expire worthless. Thus, a participant's earnings are equal to whatever amount of cash she has at the end of period 15 . Trading in each period lasts for $31 / 2$ minutes. The market setting is common knowledge to all participants. A screenshot of the market information is provided in Figure 1. 
Nine subjects were recruited for each market. They each were endowed with a starting portfolio of cash and shares. 3 types of endowments were used: (1080c, 3 shares), (720 $\dot{c}$, 4shares) and (360c, 5 shares). 3 subjects were allocated with each type of portfolio. The endowments were exactly the same as the "Share Rich" treatment of Caginalp, Porter, and Smith (2001). The endowments were the same for all sessions. Thus, all subjects started with the same expected portfolio wealth of $\$ 21.60$.
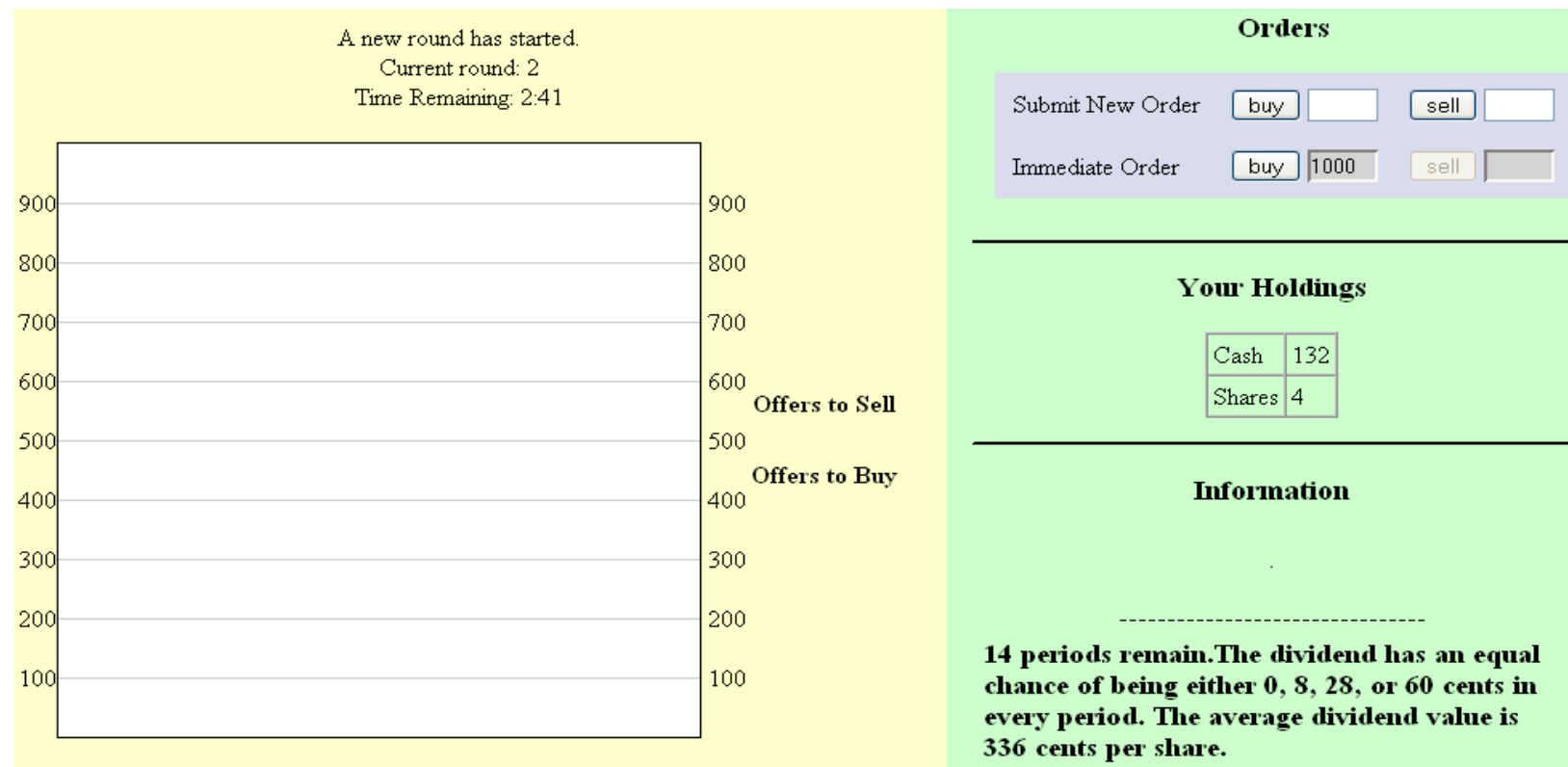

Fig. 1. Market Screen

\subsection{Accounting Method Treatments}

As stated previously, three treatments of accounting methods are tested: (M2F), (HC) and $(\mathrm{M} 2 \mathrm{M})$. At the end of a trading period, a financial report is provided to each subject. The report tells each subject their period dividend earnings and also the value of one's share holdings determined under the specific accounting rule used in that session.

In the M2F treatment each share is valued at its fundamental value, which is the remaining expected dividend value. For example, at the end of the first period, each share is valued at $24 c \times 14=336 c$; at the end of the second period, at $24 c \times 13=312 c$, etc. In practice, this value is not commonly known as it is in our experiment, but it used herein as an idealized benchmark which we can use to contrast with against the other, generally accepted accounting valuation methods. 
For the $\mathrm{HC}$ treatment each share is valued at its acquisition cost. If a share was purchased at $300 c$, it is valued at $300 c$. For the originally endowed shares, they were considered as being purchased at 360c. Since shares are likely to be purchased at different prices we use a first-infirst-out (FIFO) rule to value the inventory after a sale. For example, if a participant made 3 purchases sequentially at $300 c, 350 c$ and $400 c$, when she sells one share, the total share value based on $\mathrm{HC}$ becomes $(350 \hat{c}+400 \mathrm{c}=) 750 \mathrm{c}$.

Finally, for $\mathrm{M} 2 \mathrm{M}$, each share is valued at the closing price of a period. If no trade occurred in a period, the last trade price in the preceding period was used. This event never occurred in our experiments.

To reinforce the reported account values, we asked each subject to write down their share holding values on a piece of paper at the end of each period. The end-of-period accounting report screen can be found in Figure 2.

\section{Your Holdings}

\begin{tabular}{|c|c|c|}
\hline & Cash & 1008 \\
\hline & Shares & 3 \\
\hline Change in Loan Amou & nt: 1350 & Accept \\
\hline Cash Balance & & 1008 \\
\hline Value of shares held & & 2700 \\
\hline Total (Cash + Shares) & & 3708 \\
\hline Loans Outstanding & & 0 \\
\hline Net Worthrcash + Shares - 1 & Loan) & 3708 \\
\hline
\end{tabular}

Fig. 2. End-of-Period Financial Report

\subsection{Loan Adoption}


We evaluate the performance of accounting methods under both a No Loan (NL) and Loan (L) condition. Thus, we have a 3 accounting methods $\times 2$ loan conditions design (See Table 1). The three NL treatment end-of-period reports only list "Cash Balance", "Values of Shares Held" and "Net Worth (Cash +Shares)", without mentioning any loan related items. The three Loan treatments allow subjects to accept loans based upon the value of their shares held.

Once asset values were determined by the accounting methods, subjects in Loan treatments were allowed to borrow up to $50 \%$ of their reported asset holding values. Specifically, at the end of each period, the loan algorithm evaluated whether to offer more loans to the subject or reduce the outstanding loan amount based on a trader's share value determined by the specific accounting method. At the end of a period, a subject's debt capacity was set at $50 \%$ of her current share values. When "Loans Outstanding" was below $50 \%$ of share value, the subject was offered the option to take on more debt. In the case when Loans Outstanding exceeded $50 \%$ of share value, the excess amount was automatically reduced from the subject's cash balance (a margin call). The new loan availability (available debt capacity) was automatically reflected in "Change in Loan Amount" in the financial report at the end of each round (See Figure 2).

Loans first became available to subjects at the end of period 1. All loans matured in period 13 and were required to be repaid in full at the end of that period. At the end of period 1 through period 12 , subjects were given the option to adjust their loan amounts. All loans were provided at zero interest rate for simplicity.

A loan default was triggered when the Loans Outstanding amount had to be reduced but the trader's cash position was insufficient to cover the loan repayment. In this case, the trader's account was frozen and she could not trade until she had accumulated enough cash to cover the outstanding loan amount. In the next period, her shares were liquidated by computer algorithm until the excess loan amount was covered. The algorithm was set to automatically sell one of the liquidated shares to the highest available bid in the market every 10 seconds. Once the sale had generated enough revenue to cover the required loan repayment, the account was immediately released back to the trader. In the situation when even complete liquidation did not generate enough revenue to repay the outstanding loan, the account was closed. The subject was considered bankrupt and had zero earnings; any remaining loss was absorbed by the experimenter. 
Table 1. Design Structure

\begin{tabular}{lccc}
\hline & \multicolumn{3}{c}{ Accounting Methods } \\
\cline { 2 - 4 } Loan Condition & Fundamental Value & Historic Cost & Mark-to-Market \\
No Loan (NL) & (M2F) & (HC) & (M2M) \\
\cline { 2 - 4 } Loan (L) & 3 sessions & 3 sessions & 3 sessions \\
\hline
\end{tabular}

\subsection{Subjects, Training, and Incentives}

All participants went through intensive training for the experiment. Participants engaged in a 20-minute instruction session, which includes a slideshow with a pre-recorded reading of the instructions in a PowerPoint presentation. After the instructions were read, subjects answered a series of quiz questions about the fundamental value structure, earnings calculation, loan eligibility and requirements, and trading operations. The instructions and quiz questions are provided in Appendix.

When the instructions were concluded, subjects participated in a 2-period practice session to become familiar with the trading and accounting interfaces. Subjects were told that the practice was not related to their earnings and they should feel free to try out the program. At the end of the first practice period, the financial report was explained to them item by item. In the second period, trading continued and at the end of the period the financial report information was reviewed again.

Each participant was paid one dollar for every 100 cents earned through endowments or trading. On average, subjects made $\$ 21.86$, plus a show-up fee of $\$ 7$.

\section{Results}

Let $\bar{P}_{t}$ be the mean price of period $\mathrm{t} ; F V_{t}$ the fundamental value of period $t ; \overline{F V}$ the mean fundamental value in the market; Median $P_{t}$ the median price in period t; $N$ the total number of periods. Following Stöckl, Huber and Kirchler (2010), we analyze the following eight metrics of asset prices: 
- Magnitude: $M A G=\frac{1}{N} \sum_{t=1}^{N}\left(\bar{P}_{t}-F V_{t}\right)$.

- Price Amplitude: $P A=\max \left(\bar{P}_{t}-F V_{t}\right) / F V_{1}-\min \left(\overline{P_{t}}-F V_{t}\right) / F V_{1}$

- Total Dispersion: $T D=\sum_{t=1}^{N}\left|\operatorname{MedianP}_{t}-F V_{t}\right|$

- Average Bias: $A B=\frac{1}{N} \sum_{t=1}^{N}\left(\operatorname{MedianP}_{t}-F V\right)$

- Haessels $\mathrm{R}^{2}: H R^{2}=R^{2}$ of the OLS regression $\bar{P}_{t}=\alpha+\beta F V_{t}+\varepsilon$

- Duration: $D U R=\max \left\{N: \bar{P}_{t}-F V_{t}<\bar{P}_{t+1}-F V_{t+1}<\cdots<\bar{P}_{t+(N-1)}-F V_{t+(N-1)}\right\}$

- Relative Absolute Deviation: $R A D=\frac{1}{N} \sum_{t=1}^{N}\left|\overline{P_{t}}-F V_{t}\right| /|\overline{F V}|$

- Relative Deviation: $R D=\frac{1}{N} \sum_{t=1}^{N}\left(\overline{P_{t}}-F V_{t}\right) /|\overline{F V}|$

These eight measures all provide information on price deviations. For Magnitude, Price Amplitude, Average Bias Duration and Relative Deviation, higher values are associated with larger bubbles. Total Dispersion, Haessels $\mathrm{R}^{2}$ and Relative Absolute Deviation measure how well prices track the fundamental value and provide another perspective on mispricing.

\subsection{Accounting Treatments with no Loans}

Figure 3 plots the average price per period for the no loan cases. We also report in Table 2 the bubble characteristics for these cases. We find the typical pattern as with markets when an accounting balance sheet is not provided. In all three treatments, the markets start with undervaluations followed by overvaluations and end with a crash toward the fundamental value. However, the average price in the $\mathrm{M} 2 \mathrm{M}$ treatment is higher across periods than either the $\mathrm{HC}$ or $\mathrm{M} 2 \mathrm{~F}$ treatments. $\mathrm{M} 2 \mathrm{M}$ by itself seems to make the market more ebullient, however, no statistically significant difference between treatments is found ${ }^{5}$. We next examine how this

\footnotetext{
${ }^{5}$ Permutation tests with 1500 reps on all pairings do not produce any p-value less than 0.10 . Given the size of our sample, the power of our tests is limited.
} 
accounting interacts on the financial side of the ledger when this accounting information is used to obtain loans.

Table 2. Bubble Measures for the Accounting Treatments without Loans

\begin{tabular}{cccccccccc}
\multicolumn{10}{c}{ Bubble Measures for No Loan Sessions } \\
\hline & Magnitude & $\begin{array}{c}\text { Price } \\
\text { Amplitude }\end{array}$ & $\begin{array}{c}\text { Total } \\
\text { Dispersion }\end{array}$ & $\begin{array}{c}\text { Average } \\
\text { Bias }\end{array}$ & $\begin{array}{c}\text { Haessel } \\
\mathrm{R}^{2}\end{array}$ & Duration & $\begin{array}{c}\text { Relative } \\
\text { Average } \\
\text { Deviation }\end{array}$ & $\begin{array}{c}\text { Relative } \\
\text { Deviation }\end{array}$ \\
\cline { 2 - 9 } $\mathrm{M}$ DF & -4.98 & 0.79 & 1070.00 & -2.78 & 0.30 & 7.00 & 0.37 & -0.03 \\
$\mathrm{HC}$ & -7.91 & 0.67 & 962.17 & -6.32 & 0.35 & 9.00 & 0.34 & -0.04 \\
$\mathrm{M} 2 \mathrm{M}$ & 56.76 & 0.78 & 1266.33 & 53.84 & 0.46 & 10.33 & 0.44 & 0.30 \\
\hline
\end{tabular}

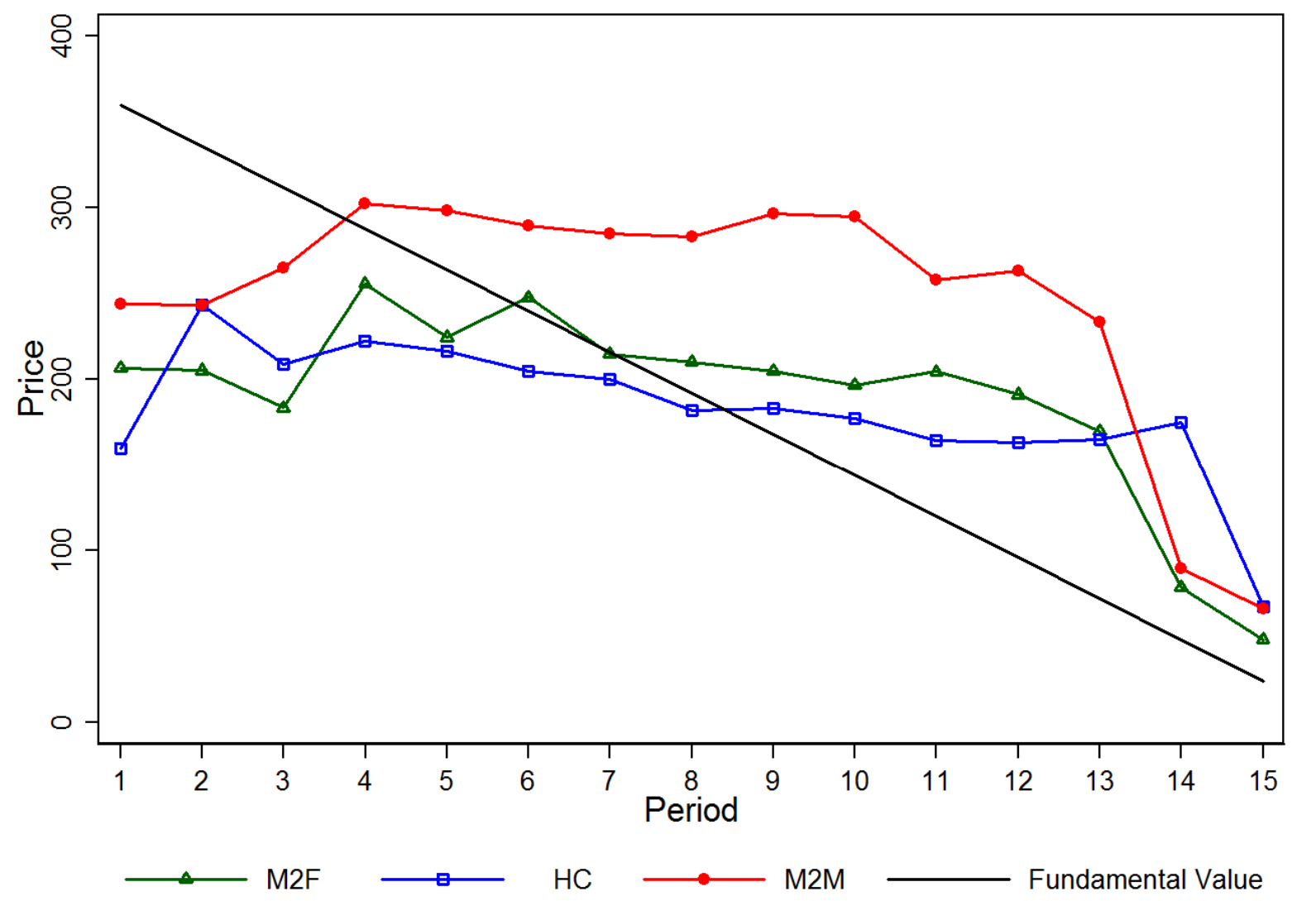

Fig. 3. Mean Prices for No Loan treatments 


\subsection{Accounting Treatments with Loans}

Figure 4 plots the average transaction prices across periods for the loan cases. As can be seen, M2M markets have higher mean prices than HC markets in all 15 periods. M2F has higher average prices than $\mathrm{HC}$ in all periods but the last two periods. Comparing M2M with M2F, the prices in the M2M markets start lower than the corresponding prices in M2F markets, then are higher in periods 10 through 15 . Overall, the loan markets produce higher prices than the no loan markets. ${ }^{6}$ This is not surprising since there is increased liquidity in periods 2-13 as traders take on more debt.

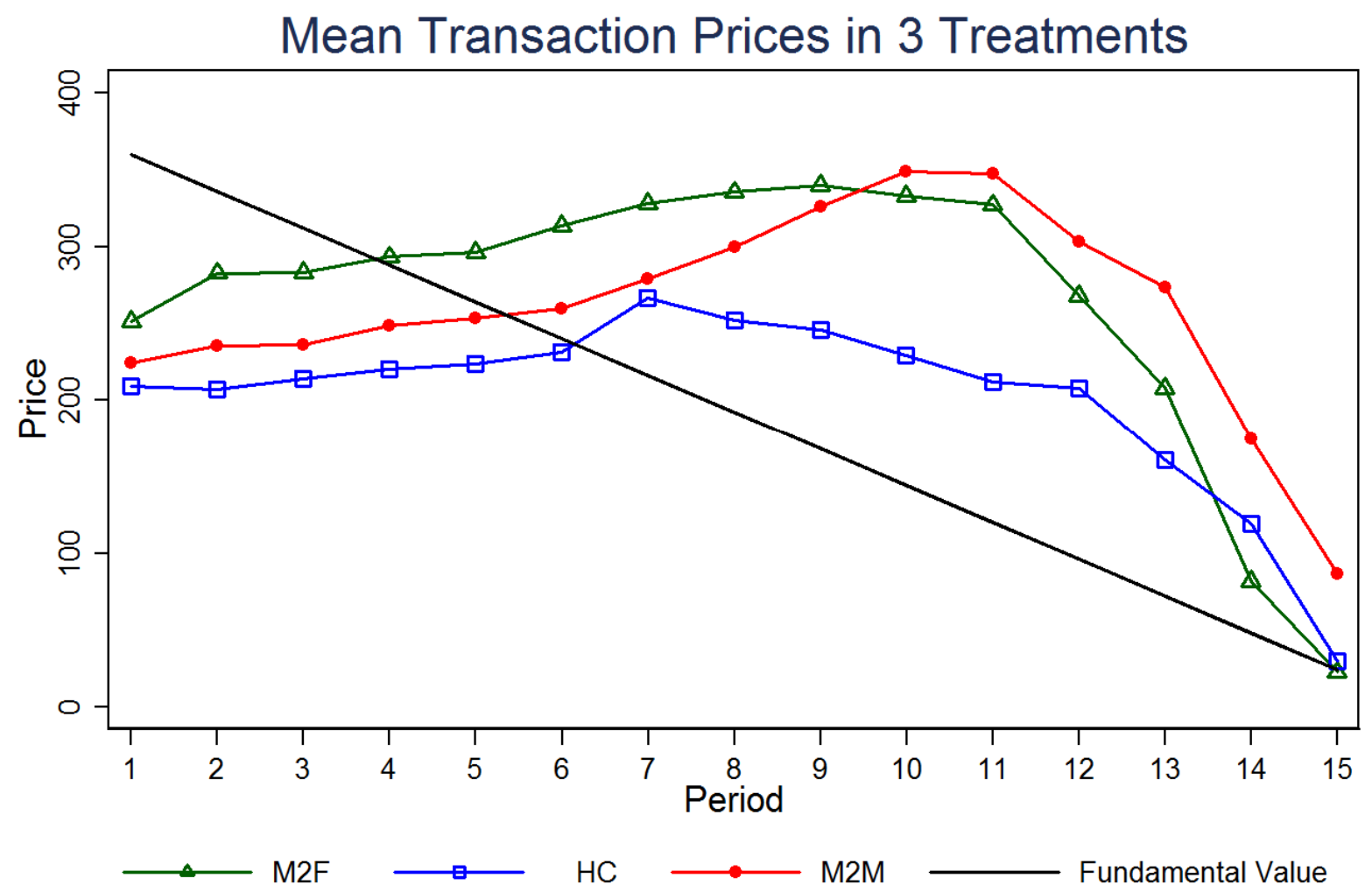

Fig. 4. Mean Prices for Loan Treatments

Table 3 Panel A reports the means of each bubble measure across treatments for the loan cases; Panel B provides $p$-values from student $t$ tests (1-sided, assuming equal variances) on

\footnotetext{
${ }^{6}$ The magnitude, price amplitude and duration of the bubbles were higher for the loan (L) markets than for the no loans (NL) markets for each of the three accounting method treatments. These differences are statistically significant based on a one-sided permutation test on the pooled data (magnitude: $p=0.08$, price amplitude: $p<0.01$, duration: $p=0.04)$.
} 
treatment difference. One striking result is that even if we report asset prices in the accounting reports at the known fundamental value (M2F) we still get bubbles that are similar to those that are generated using either of the standard accounting methods to value assets. However, between the two standard methods of asset valuation ( $M 2 M$ and $H C$ ), there is a difference in the character of the bubbles. In particular, the size of the bubble and extent of asset mispricing are significantly larger under M2M. One reason for this difference is the effect on market leverage that is created from these two methods. We examine this feature of our experimental design next.

Table 3. Bubble Measures for the Accounting Treatments with Loans

Panel A: Bubble Measures for Loan Sessions

\begin{tabular}{ccccccccc}
\hline & Magnitude & $\begin{array}{c}\text { Price } \\
\text { Amplitude }\end{array}$ & $\begin{array}{c}\text { Total } \\
\text { Dispersion }\end{array}$ & $\begin{array}{c}\text { Average } \\
\text { Bias }\end{array}$ & $\begin{array}{c}\text { Haessel } \\
\mathrm{R}^{2}\end{array}$ & $\begin{array}{c}\text { Ruration } \\
\text { M2F }\end{array}$ & $\begin{array}{c}\text { Relative } \\
\text { Absolute } \\
\text { Deviation }\end{array}$ & $\begin{array}{c}\text { Relative } \\
\text { Deviation }\end{array}$ \\
\cline { 2 - 9 } & $\mathbf{7 2 . 4 0}$ & 0.97 & 1580.33 & $\mathbf{7 2 . 8 4}$ & 0.31 & 9.67 & 0.542 & $\mathbf{0 . 3 8}$ \\
& $(33.64)$ & $(0.33)$ & $(504.42)$ & $(33.76)$ & $(0.26)$ & $(2.42)$ & $(0.17)$ & $(0.18)$ \\
$\mathrm{HC}$ & 8.77 & 0.90 & 1577.58 & 8.11 & 0.36 & 11.17 & 0.540 & 0.04 \\
& $(88.07)$ & $(0.30)$ & $(603.59)$ & $(88.24)$ & $(0.32)$ & $(2.32)$ & $(0.21)$ & $(0.46)$ \\
& & & & & & & & \\
$\mathrm{M} 2 \mathrm{M}$ & $\mathbf{7 1 . 8 9}$ & $\mathbf{1 . 2 3}$ & $\mathbf{1 8 9 4 . 1 7}$ & 68.68 & $\mathbf{0 . 0 8}$ & $\mathbf{1 1 . 8 3}$ & $\mathbf{0 . 6 7}$ & 0.37 \\
& $(62.03)$ & $(0.39)$ & $\mathbf{( 5 8 8 . 8 6 )}$ & $(59.16)$ & $(0.10)$ & $(1.33)$ & $(0.21)$ & $(0.32)$ \\
\hline
\end{tabular}

Standard deviations in parenthesis: 6 observations in each treatment. The numbers in bold represent the highest values across 3 treatments.

Panel B: Student $t$ test within Loan Sessions ${ }^{7}$

\begin{tabular}{|c|c|c|c|c|c|c|c|c|}
\hline & Magnitude & $\begin{array}{c}\text { Price } \\
\text { Amplitude }\end{array}$ & $\begin{array}{c}\text { Total } \\
\text { Dispersion }\end{array}$ & $\begin{array}{c}\text { Average } \\
\text { Bias }\end{array}$ & $\begin{array}{c}\text { Haessel } \\
\mathrm{R}^{2}\end{array}$ & Duration & $\begin{array}{c}\text { Relative } \\
\text { Absolute } \\
\text { Deviation }\end{array}$ & $\begin{array}{c}\text { Relative } \\
\text { Deviation }\end{array}$ \\
\hline $\begin{array}{l}\text { M2F } \\
\text { v.s. } \\
\text { HC }\end{array}$ & $0.065^{*}$ & 0.353 & 0.497 & $0.062^{*}$ & 0.381 & 0.149 & 0.493 & $0.064 *$ \\
\hline $\begin{array}{c}\mathrm{HC} \\
\text { v.s. } \\
\text { M2M }\end{array}$ & $0.091 *$ & $0.068^{*}$ & 0.190 & $0.096^{*}$ & $0.033 * *$ & 0.277 & 0.161 & $0.091^{*}$ \\
\hline $\begin{array}{l}\text { M2M } \\
\text { v..s } \\
\text { M2F }\end{array}$ & 0.493 & 0.126 & 0.172 & 0.442 & $0.037^{* *}$ & $0.042 * *$ & 0.143 & 0.493 \\
\hline
\end{tabular}

${ }^{7}$ None of the results change if we assume unequal variances across treatments. 


\subsection{Loan Activity}

Table 4, Panel A lists the average amount of total debt in the three treatments. Panel B formally tests the differences with a two-sample $t$ test with equal variances and with a twosample Mann-Whitney test. Again, there is no statistical difference in the debt levels in the $\mathrm{M} 2 \mathrm{M}$ and $\mathrm{HC}$ treatments relative to using fundamental value accounting ( $\mathrm{M} 2 \mathrm{~F}$ treatment). However, M2M markets have significantly higher debt levels than $\mathrm{HC}$ markets. A major reason for this difference is that $\mathrm{HC}$ and $\mathrm{M} 2 \mathrm{~F}$ generate lower average loan capacity amounts (3463 and 3672 respectively) than $\mathrm{M} 2 \mathrm{M}$ (5111). In addition, $\mathrm{HC}$ has a lower average utilization of the loan capacity (45\%) than M2F (55\%) and M2M (49\%).

The higher amounts of debt in $\mathrm{M} 2 \mathrm{M}$ and $\mathrm{M} 2 \mathrm{~F}$ coincide with the higher magnitude and amplitude of the bubbles relative to HC. The liquidity provided by loan availability appears to be fueling the bubble. We formally test this observation using Fama-MacBeth Regression (Fama and MacBeth, 1973). We have 18 markets with 12 periods in each where subjects can take out loans. The Fama-MacBeth regression corrects for the fact that each market is autocorrelated. We begin by first regressing each period's mean price against the corresponding total debt level for every market; second, we measure the average and the standard errors of the coefficients obtained from the first step across 18 markets. The standard errors correct for time-series correlation. Table 5 provides the regression results. The debt variable has positive and significant on the mean price in each period. This is consistent with the findings of Caginalp, Porter and Smith (2001) that liquidity fuels bubbles. Given the debt exposure in these markets, we now turn to default behavior in these markets.

Table 4. Debt Levels

\begin{tabular}{lc} 
Panel A & \\
\hline Treatment & Average Total Debt per Period \\
\hline \multirow{2}{*}{ M2F } & 2023.5 \\
& $(543.7)$ \\
HC & 1574.0 \\
& $(1146.1)$ \\
M2M & 2507.6 \\
& $(1045.2)$ \\
\hline
\end{tabular}

Standard deviations in parenthesis. 6 observations in each treatment. 


\begin{tabular}{|c|c|c|}
\hline Null Hypothesis & $\begin{array}{l}t \text { test } \\
p \text {-value }\end{array}$ & $\begin{array}{l}\text { Mann-Whitney } \\
\text { Test } \\
p \text {-value }\end{array}$ \\
\hline Loan (M2F) $\geq \operatorname{Loan}(\mathrm{M} 2 \mathrm{M})$ & 0.169 & 0.100 \\
\hline Loan (HC) $\geq \operatorname{Loan}(\mathrm{M} 2 \mathrm{M})$ & $0.086 *$ & $0.055^{*}$ \\
\hline Loan (HC) $\geq \operatorname{Loan}(\mathrm{M} 2 \mathrm{~F})$ & 0.203 & 0.261 \\
\hline
\end{tabular}

* indicates 0.10 significance.

Table 5. Fama-MacBeth Regression on the Effect of Debt on Market Price

\begin{tabular}{lcrrr}
\hline Mean Price & Coef. & Std. Err. & t-stat & P>t \\
\cline { 2 - 5 } & & & & \\
Debt & 0.055 & 0.004 & 12.46 & 0.000 \\
constant & 155.623 & 4.866 & 31.98 & 0.000 \\
\hline $\mathrm{n}=216$, R-squared $=0.372$ & & &
\end{tabular}

\subsection{Defaults}

At any point during the experiment if the investor's net worth cannot cover the amount of her outstanding loans, then the investor is considered in default and her assets must be sold to service the loans. ${ }^{8}$ When a default occurs, the defaulter's shares are taken into custody and sold to the current highest market bid at 10 seconds intervals. Once the raised capital from liquidation is sufficient to cover the payback short fall, the defaulter's remaining shares are returned and the trading restriction is removed.

All loans were are due in period 13. At this point, the investor must have enough cash on hand to cover the loans or the default condition is triggered.

No default was observed in any of the M2F markets, while a third of the HC markets and half of the M2M markets experienced default. In each of those markets, the default event was limited to a single trader. Figure 5 plots the trading prices (including the liquidating trades indicated with a red $\Delta$ ), together with the Total Debt (the dashed line) in each trading period. All the defaults involved a high level of debt except the default in Market 4 of the HC treatment where the default involved the liquidation of just one share.

\footnotetext{
${ }^{8}$ Default never occurred before period 13 in any market.
} 

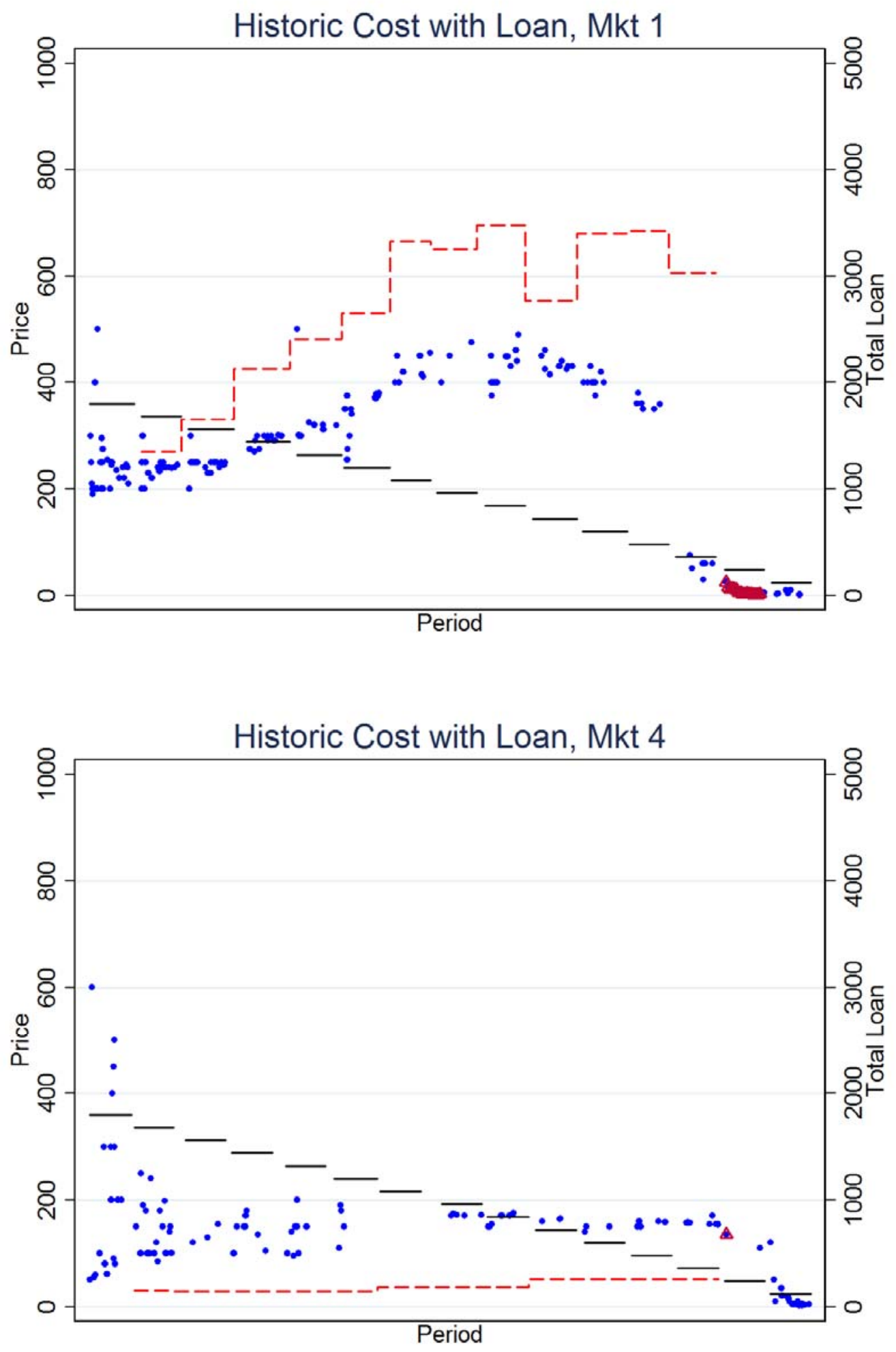

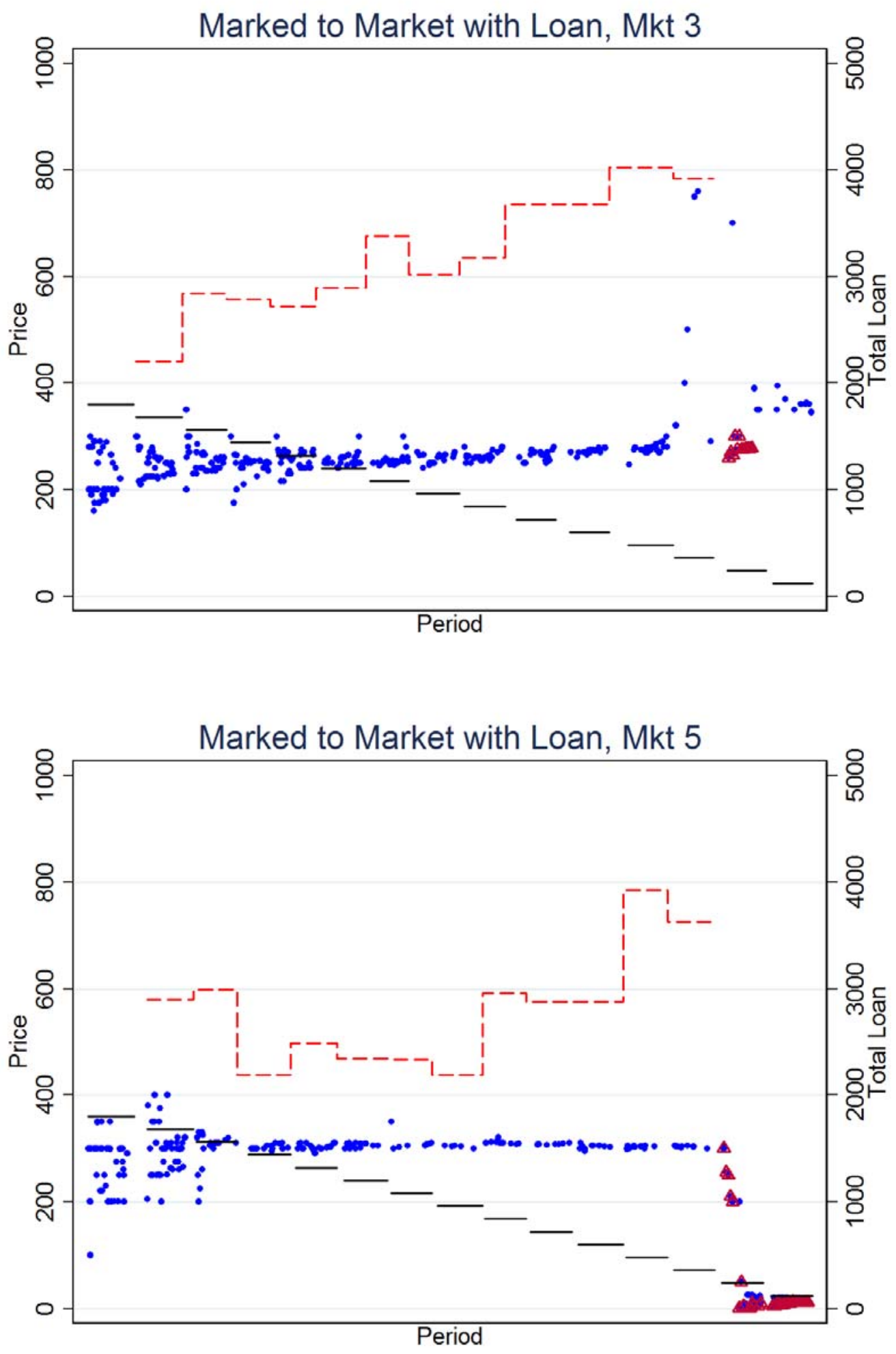


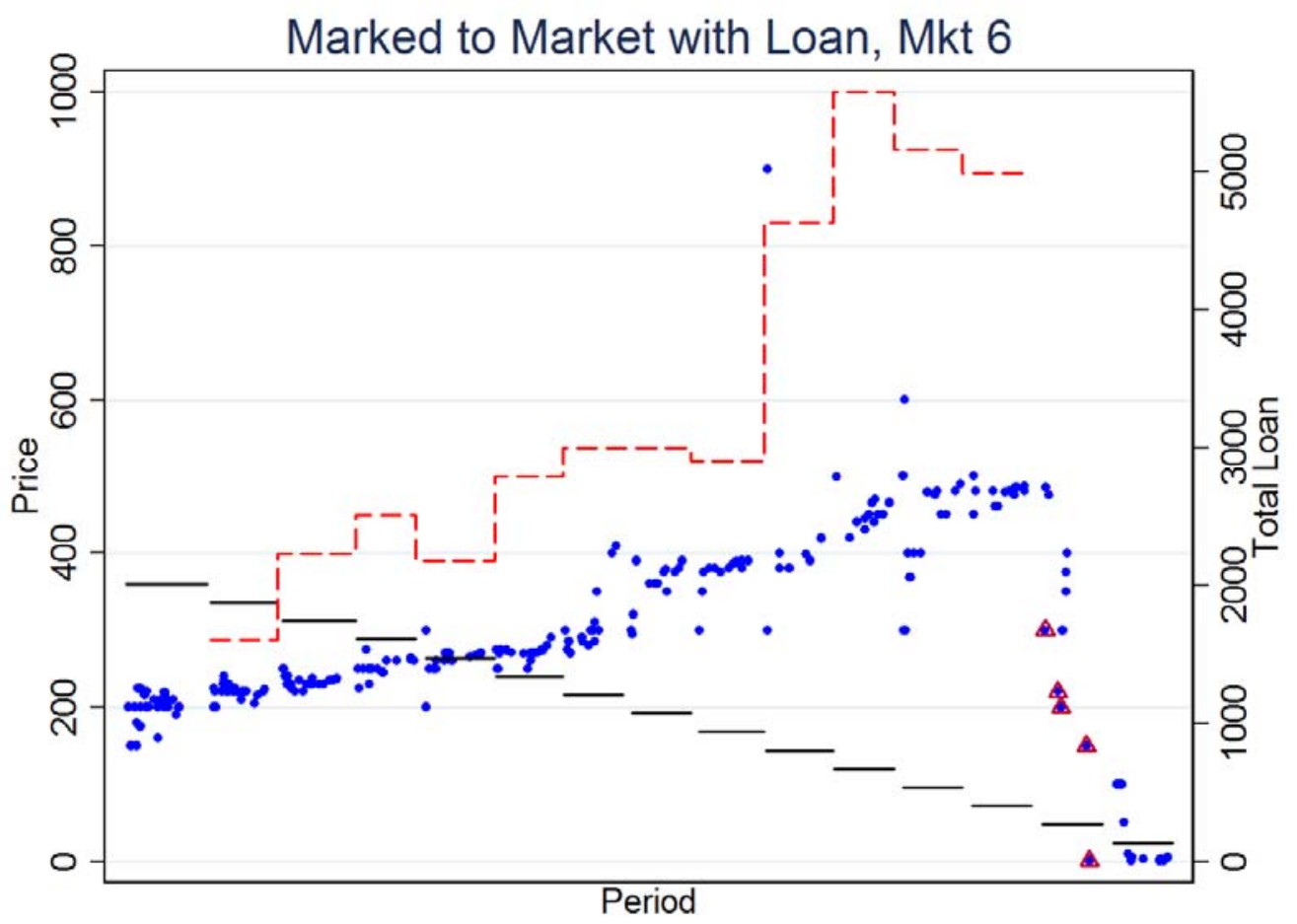

- Trade $\Delta$ Liquidation - - Aggregate Loan — Fundamental Value

Fig. 5. Markets with Defaults

Table 6 provides the details of the five defaults. What stands out is the size of the price crash following the default. The average price fall in the two HC markets is 42.7 cents while in the three M2M markets the average crash in price is 194.8 . 
Table 6. Default Details and Market Crash

\begin{tabular}{|c|c|c|c|c|c|c|}
\hline $\begin{array}{l}\text { Session } \\
\text { Name }\end{array}$ & $\begin{array}{c}\text { Shares } \\
\text { Liquidated }\end{array}$ & $\begin{array}{c}\text { Defaulter's } \\
\text { Cash } \\
\text { Shortage } \\
\text { in Period } \\
13\end{array}$ & $\begin{array}{l}\text { Average } \\
\text { Liquidating } \\
\text { Price in } \\
\text { Period } 14\end{array}$ & $\begin{array}{c}\text { Average } \\
\text { Trading } \\
\text { Price in } \\
\text { Period } \\
13\end{array}$ & $\begin{array}{l}\text { Average } \\
\text { Trading } \\
\text { Price in } \\
\text { Period } \\
14\end{array}$ & $\begin{array}{l}\text { Price Crash } \\
\text { from Period } \\
13 \text { to } 14\end{array}$ \\
\hline $\mathrm{HC}-\mathrm{Mkt1}$ & 17 & 1428 & 6.8 & 55.7 & 5.9 & -49.8 \\
\hline HC-Mkt4 & 1 & 12 & 135.0 & 158.0 & 122.5 & -35.5 \\
\hline M2M - Mkt3 & 12 & 3160 & 277.4 & 503.3 & 319.9 & -183.4 \\
\hline M2M - Mkt5 & 30 & 2820 & 100.2 & 303.3 & 83.3 & -220.0 \\
\hline M2M - Mkt6 & 5 & 1033 & 174.2 & 477.0 & 296.0 & -181.0 \\
\hline
\end{tabular}




\subsection{Financial Leverage}

Financial leverage is typically measured as the ratio of total debt to total assets. We employ two definitions of this ratio - a book debt ratio based on reported accounting numbers and a debt ratio based on fundamental value. The book debt ratio is defined as follows:

$$
\text { Book Debt Ratio }=\frac{\text { Liabilities }}{\text { Total Assets on Book }}=\frac{\text { Loans }}{\text { Cash }+ \text { Share Accounting Value }}
$$

In Figure 6 we chart the average book debt ratio for each period and treatment. Each treatment results in a slight downward trend in this ratio. Fundamental value accounting creates an automatic deleveraging effect as traders are forced to maintain a loan balance at less than or equal to $50 \%$ of the reported share value. Hence, the numerator in the ratio declines while the denominator in the ratio remains relatively constant. The decreasing ratio reflects the declining amount of outstanding loans. In contrast, the reported value of the shares does not decrease in the $\mathrm{HC}$ markets and increases over time in the M2M markets, even as cash dividends are paid. Under both accounting regimes, the denominator in the book debt ratio increases each period until the bubble bursts, causing the book debt ratio to trend downward even as loan balances are increasing.

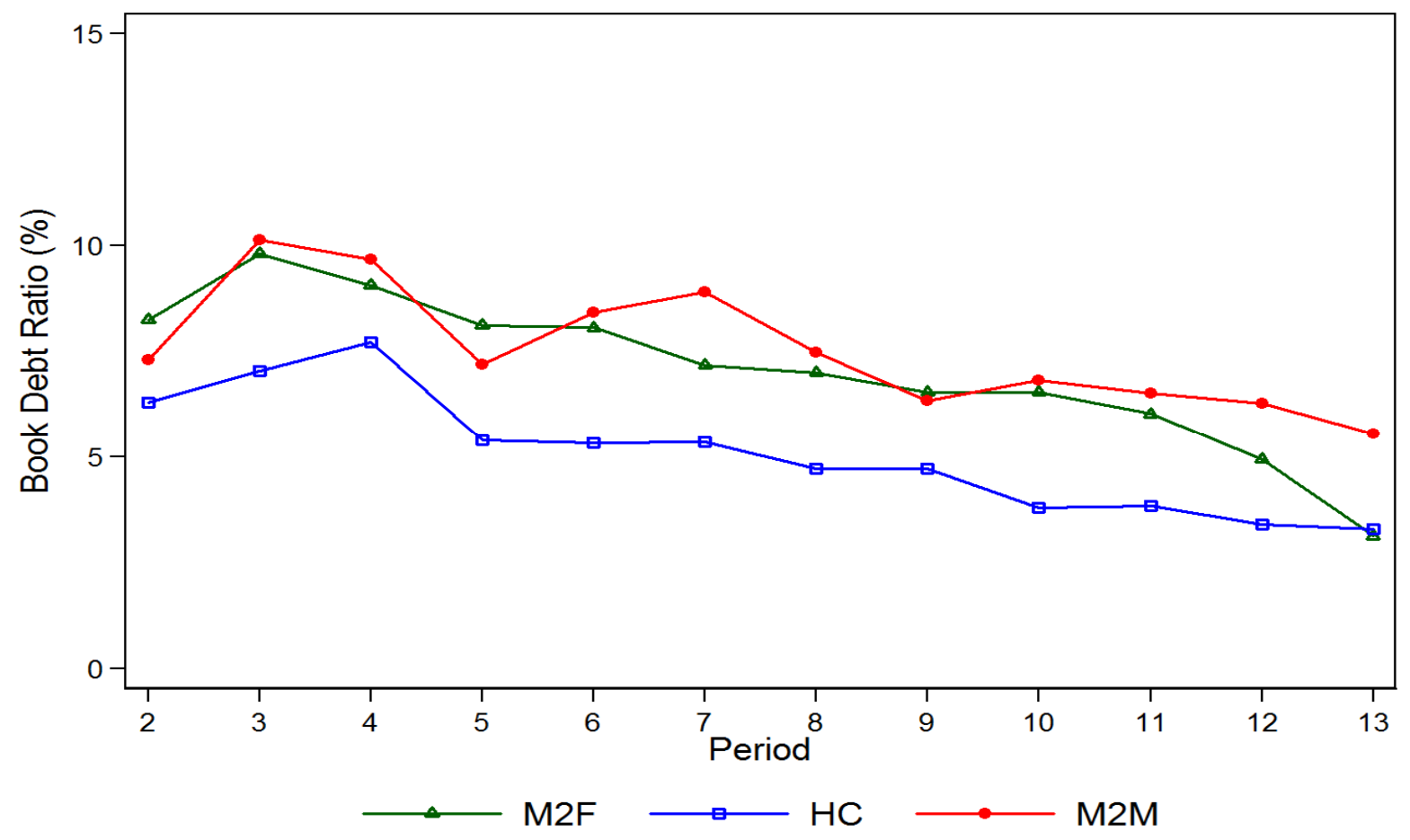

Fig. 6. Book Debt Ratio over Time for Three Accounting Treatments 
A different perspective on leverage is provided by the debt ratio. The debt ratio differs from the book debt ratio only in the denominator value of the shares held. Instead of using shares' book values reported under each accounting alternative, we use shares' fundamental values. The book debt ratio can be interpreted as a nominal measure of financial leverage, while actual leverage is measured by the debt ratio:

$$
\text { Debt Ratio }=\frac{\text { Liabilities }}{\text { Total Assets }}=\frac{\text { Loans }}{\text { Cash }+ \text { Share Fundamental Value }}
$$

Figure 7 plots the mean debt ratio among the individual traders in each period for each treatment. In period 13 , the $\mathrm{M} 2 \mathrm{M}$ traders have the highest average debt ratio while $\mathrm{M} 2 \mathrm{~F}$ subjects have the lowest. The level of individual indebtedness explains why M2M is most prone to defaults and $\mathrm{M} 2 \mathrm{~F}$ is immune to defaults.

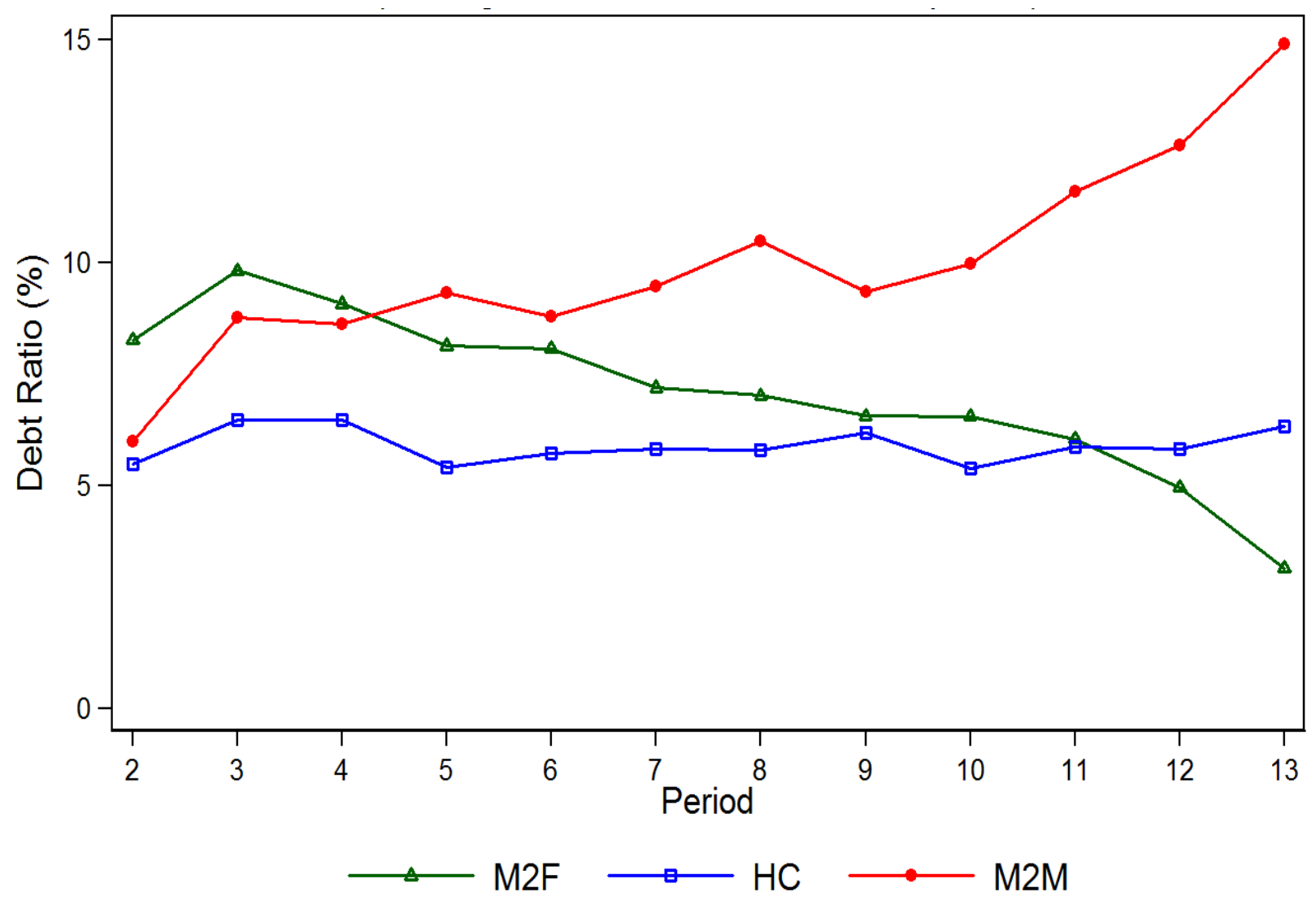

Fig. 7. Debt Ratio over Time for Three Accounting Treatments 
The book debt ratio gives the impression that financial leverage is decreasing over time. This is true in the $\mathrm{M} 2 \mathrm{~F}$ markets, where the declining fundamental value forces traders to de-leverage as the experiment progresses. However, in the $\mathrm{HC}$ markets, actual financial leverage remains relatively constant while in the $\mathrm{M} 2 \mathrm{M}$ markets, actual leverage is increasing. The inflated reported value of the shares in the $\mathrm{HC}$ and $\mathrm{M} 2 \mathrm{M}$ markets gives the impression that the trader has assets of sufficient value to cover the loan, even as the loan balance is increasing. In fact, when the trader tries to liquidate shares to repay the loan in period 13 , the market price crashes to fundamental value and the true level of financial leverage is revealed.

Table 7 compares the average debt ratios and book debt ratios in Period 13 for all 18 markets as well as these two ratios for the individual traders who defaulted in each market.

Table 7. Debt Ratio(\%), Book Debt Ratio (\%) and Defaults at Maturity (Period 13)

\begin{tabular}{|c|c|c|c|c|c|c|}
\hline \multirow[b]{2}{*}{ Treatment } & \multirow[b]{2}{*}{ MKT } & \multirow[b]{2}{*}{$\begin{array}{l}\text { Debt } \\
\text { Ratio }\end{array}$} & \multirow[b]{2}{*}{$\begin{array}{c}\text { Book Debt } \\
\text { Ratio }\end{array}$} & \multirow[b]{2}{*}{$\begin{array}{l}\text { Anyone } \\
\text { Default? }\end{array}$} & \multicolumn{2}{|c|}{ Defaulters } \\
\hline & & & & & $\begin{array}{l}\text { Debt } \\
\text { Ratio }\end{array}$ & $\begin{array}{c}\text { Book Debt } \\
\text { Ratio }\end{array}$ \\
\hline \multirow{7}{*}{$\mathrm{M} 2 \mathrm{~F}^{*}$} & 1 & 5.4 & 5.4 & No & & \\
\hline & 2 & 4.8 & 4.8 & No & & \\
\hline & 3 & 1.8 & 1.8 & No & & \\
\hline & 4 & 1.9 & 1.9 & No & & \\
\hline & 5 & 3.8 & 3.8 & No & & \\
\hline & 6 & 7.2 & 7.2 & No & & \\
\hline & mean & 4.1 & 4.1 & & & \\
\hline \multirow{7}{*}{$\mathrm{HC}$} & 1 & 15.0 & 6.2 & Yes & 110.7 & 32.5 \\
\hline & 2 & 4.7 & 3.2 & No & & \\
\hline & 3 & 0.2 & 0.2 & No & & \\
\hline & 4 & 4.2 & 2.3 & Yes & 38.0 & 21.0 \\
\hline & 5 & 8.4 & 4.0 & No & & \\
\hline & 6 & 5.5 & 3.9 & No & & \\
\hline & mean & 6.3 & 3.3 & & & \\
\hline \multirow{7}{*}{$\mathrm{M} 2 \mathrm{M}$} & 1 & 2.1 & 1.6 & No & & \\
\hline & 2 & 8.0 & 4.8 & No & & \\
\hline & 3 & 17.5 & 5.7 & Yes & 144.2 & 40.0 \\
\hline & 4 & 8.5 & 6.2 & No & & \\
\hline & 5 & 17.4 & 6.3 & Yes & 129.9 & 31.7 \\
\hline & 6 & 18.1 & 8.5 & Yes & 89.1 & 24.9 \\
\hline & mean & 11.9 & 5.6 & & & \\
\hline
\end{tabular}

* By definition, the debt ratio is identical to the book debt ratio for M2F markets. These values are included for comparison purposes. 
Comparing the debt ratio to the book debt ratio in each market indicates the extent to which financial leverage is understated by the book debt ratio. In all of the M2M markets and all but one of the $\mathrm{HC}$ markets, the actual debt ratio is greater than the book debt ratio. In the HC markets, the mean debt ratio is $6.3 \%$ compared to an average book debt ratio of $3.3 \%$. In the $\mathrm{M} 2 \mathrm{M}$ markets, the difference is more dramatic; the mean debt ratio of $11.9 \%$ is more than double the average book debt ratio of 5.6\%. Moreover, the markets experiencing defaults have higher debt ratios relative to other markets in the same treatments, while their book debt ratios are much closer to the average. Table 7 suggests that these defaulters' balance sheets look healthy on paper, while, in fact, they are set up for a difficult deleveraging event.

\section{Conclusions}

We conduct 27 laboratory markets in which subjects were allowed to trade shares of an asset that paid a cash dividend at the end of each of fifteen trading periods. At the end of each period subjects were presented with a balance sheet detailing their cash position and the value of their shares. The main focus of our study is the effect of alternative accounting methods for valuing assets and their effect on potential asset mispricing.

Our experimental design uses a well-studied environment that reliably produces bubbles and crashes in asset prices. We use this environment to stress test three accounting methods: Mark-to-Market (M2M), Historical Cost ( $\mathrm{HC})$, and Mark-to-Fundamental value (M2F). These methods were used to report asset values in a balance sheet to show subjects their net worth position. In addition, a treatment was created to link asset value on individual balance sheets to the ability of subjects to take out loans to increase their cash position. In the treatment when loans are absent, the accounting effects are hardly distinguishable. That is, there seems to be no link between the reporting of balance sheet asset values and the characteristics of the price bubbles. However, in the loan treatments, the bubbles are exacerbated and the characteristics of the bubbles were related to the accounting method used to report asset values.

We examine the leveraging process under each accounting alternative. Overall, $\mathrm{M} 2 \mathrm{M}$ and $\mathrm{M} 2 \mathrm{~F}$ have higher loan presence than $\mathrm{HC}$, and these two have similar loan levels. It is this enhanced liquidity that helps explains the size of bubbles. When asset prices are inflated on the balance sheet, the indebtedness of individual holdings is naturally understated. Both $\mathrm{M} 2 \mathrm{M}$ and $\mathrm{HC}$ accounting systematically understate the actual debt-to-asset ratios, with their balance sheets appearing healthy on paper. M2M markets experienced the worst market crashes and the most frequent loan defaults. HC markets suffer from the same debt understatement, however, the leverage is limited and thus the deleveraging damage is less severe. 
$\mathrm{M} 2 \mathrm{M}$ and $\mathrm{M} 2 \mathrm{~F}$ also differ in leverage levels at different points of time. We find that in M2M markets the debt ratio steadily increases over time, which makes M2M markets prone to default at loan maturity. In contrast, debt ratios in the M2F markets gradually decrease as the falling fundamental value provides an automatic built-in deleveraging mechanism. This feature of $\mathrm{M} 2 \mathrm{~F}$ makes them completely immune to defaults.

Our study demonstrates that the relevance of $\mathrm{M} 2 \mathrm{M}$ or $\mathrm{HC}$ accounting depends on how well market prices reflect fundamentals (directly or indirectly). When reported asset values depart from fundamental value, markets are vulnerable to costly mistakes and corrections. 


\section{References}

Barth, M. (1994). 'Fair value accounting: Evidence from investment securities and the market valuation of banks', The Accounting Review, vol. 69(1), pp. 1-25.

Barth, M., Landsman, W. and Wahlen, J. (1995). 'Effect of bank earnings volatility, regulatory capital, and valuation contractual cash flows', Journal of Banking and Finance, vol. 19, pp. 577-605.

Caginalp, G., Porter, D. and Smith, V. (2001). 'Financial bubbles: excess Cash, momentum, and incomplete information', Journal of Psychology and Financial Markets, vol. 2, pp. 80-99.

Carey, M. (1995). 'Partial market value accounting, bank capital volatility, and bank risk', Journal of Banking and Finance, vol. 19, pp. 607-22.

Cornett, M., Rezaee, Z. and Tehranian, H. (1996). 'An investigation of the capital market reactions to pronouncements on fair value accounting', Journal of Accounting and Economics, vol. 22, pp. 119-54.

Dufwenberg, M., Lindqvist, T. and Moore, E. (2005). 'Bubbles and experience: an experiment', American Economic Review, vol. 95, 1731-37.

Eccher, E., Ramesh, K. and Thiagarajan, R. (1996). 'Fair value disclosures by bank holding companies', Journal of Accounting and Economics, vol. 22, pp. 79-117.

Fama, E. and MacBeth, J. (1973). 'Risk, return, and equilibrium: empirical tests', Journal of Political Economy, vol. 81(3), pp. 607-36.

Kirchler, M., Huber, J. and Stöckl, T. (2012). Thar She Bursts: Reducing Confusion Reduces Bubbles, American Economic Review, vol. 102(2), pp. 865-83.

Lei, V., Noussair, C. and Plott, C. (2001). 'Nonspeculative bubbles in experimental asset markets: lack of common knowledge of rationality vs. actual irrationality', Econometrica, vol. 69, pp. 831-59.

Morris, C. and Sellon, G. (1991). 'Market value accounting for bankers: pros and cons', Economic Review, Federal Reserve Bank of Kansas City (March/April), pp. 5-19.

Noussair, C., Robin, S. and Ruffieux, B. (2001). 'Price bubbles in laboratory asset markets with constant fundamental values', American Economic Review, vol. 97, pp. 1901-20.

Palan, S. (2014). 'A review of bubbles and crashes in experimental asset markets', Journal of Economic Surveys, vol. 27(3), pp. 570-88.

Reshmaan, H., Porter, D. and Smith, V. (2008). 'Thar she blows: can bubbles be rekindled with experienced subjects?', American Economic Review, vol. 98, pp. 924-37.

Stöckl, T., Huber, J. and Kirchler, M. (2010). 'Bubble measures in experimental asset markets', Experimental Economics, vol. 13, pp. 284-98. 
Smith, V., Suchanek, G. and Williams, A. (1988). 'Bubbles, crashes, and endogenous expectations in experimental spot asset markets', Econometrica, vol. 56, pp. 1119-51.

Wesbury, B. (2009). 'It's not as bad as you think', John Wiley \& Sons, Inc., Hoboken, New Jersey. 


\section{Appendix: Instructions}

This is an experiment in market decision making. You will be paid in cash for your participation at the end of the experiment. The amount of cash that you earn will depend upon your decisions and the decisions of other participants.

The experiment will take place at the computer terminals at which you are seated. If you have any questions during the instructions or during the practice round, please raise your hand and a monitor will come by to answer your question. If you experience any difficulties after the experiment has begun, please raise your hand and someone will assist you.

\section{The Situation}

At the start of the experiment, each participant will be given some cash and some shares.

The experiment will last 15 rounds. Each round will last 3 minutes. In each round, you will be able to buy and sell shares in the market. When you buy a share, the purchase price is deducted from your cash. When you sell a share, the price is added to your cash.

At the end of the experiment, you will be paid an amount equal to the amount of cash you have in your cash account.

At the end of each round, you will be paid a cash dividend for each share that you own. The more shares you own, the more dividends you will be able to earn. The dividends will be added to your cash account.

The amount of the dividend per share can be one of four amounts: 0, 8, 28 or 60 cents per share. Each of these four possible dividend amounts is equally likely.

That is, at the end of each round, the computer will randomly choose a dividend amount from the four possible amounts, and each share pays its owner a cash dividend equal to that amount.

The average dividend per share is $24 c$, calculated by summing the four possible dividend amounts and then dividing the total by $4:(0+8+28+60) / 4=24 \mathrm{c}$. That is, over several rounds, the average dividend amount per share is $24 \mathrm{c}$.

If you hold a share from round 1 through round 15 , the share will pay you 15 dividends. Because the average dividend is $24 c$ per round, each share should pay, on average, $360 c$ if held for 15 rounds ( $15 \mathrm{x}$ $24=360)$.

The total dividend amount that you earn can be as low as $0 c(15 \times 0)$, if all 15 dividends equal $0 c$; the total can be as high as $900 c(15 \times 60)$, if all 15 dividends equal $60 c$. However, each of the 4 possible dividend amounts is equally likely to occur each round, so it is unlikely that the dividend will be the same amount for all 15 rounds. 
If you purchase a share in the $2^{\text {nd }}$ round and hold it until the end of the $15^{\text {th }}$ round it will pay 14 dividends. The total amount of dividends earned can be as high as $840 c(14 \times 60)$ or as low as $0 c(14 \times 0)$; on average, a share held for 14 rounds will earn 336c (14 x 24).

Similarly, if you hold a share for 13 rounds, it will pay 13 dividends; on average, a share held for 13 rounds will earn $312 c(13 \times 24)$.

In other words, the more shares you own and the longer you hold each share, the more you can earn in dividends.

However, at the end of the experiment, the shares expire and will be worth nothing. Your earnings will be determined solely by the amount of cash that you hold at the end of the experiment.

[Below section is added to the LOAN treatments.]

At the end of each round, you will be given the opportunity to borrow additional cash, which can be used to purchase more shares in the next round.

The amount that you borrow may not exceed $50 \%$ of the value of your shares. Thus, if you own shares valued at $500 c$, you may borrow up to $250 c$.

As long as your outstanding loan amount is less than $50 \%$ of your share value, you will be able to borrow additional cash. The more shares you have the more you may borrow.

The cash in your account at the end of a round, plus the amount you borrow, will carry over to the beginning of the next round along with your shares.

If your outstanding loan amount is more than $50 \%$ of your share value, you will need to repay some or all of your loan. This loan repayment will be deducted from your cash.

In addition, all loans will be repaid at the end of the $13^{\text {th }}$ round.

If you have insufficient cash to repay your loan, you will be in default. The computer will sell your shares to repay the loan. Once your loan is repaid, any remaining cash or shares will be returned to your account and you can resume trading.

\section{How to Trade Shares?}

When the market for shares opens, a screen like the one below will appear. Next we explain each part of the screen. 

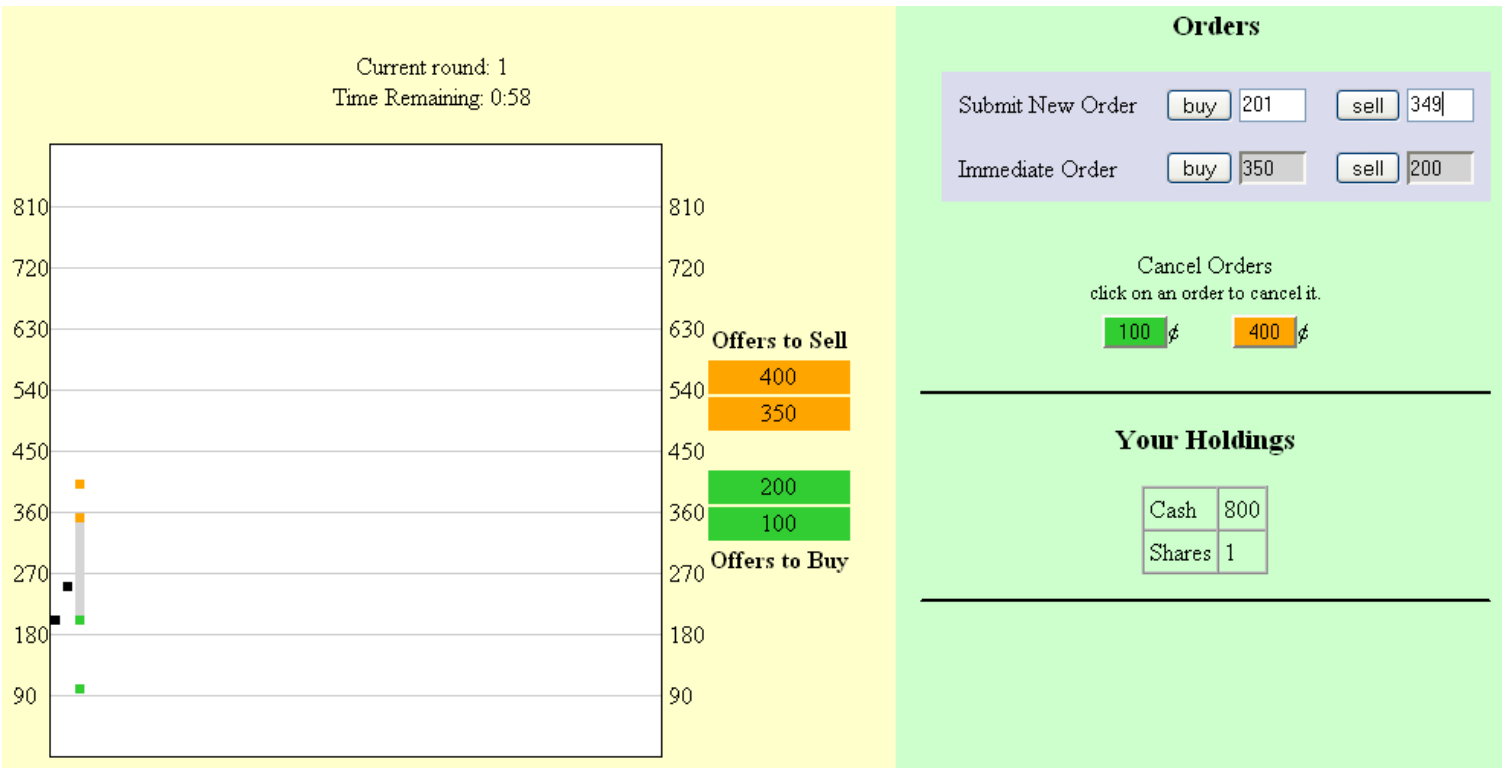

The section of the screen labeled "Your Holdings" shows how much cash you have and how many shares you own.

Existing offers to buy or sell shares are shown on the graph to the left.

The current round and the time remaining in the round is presented at the top of the graph.

Offers to buy and sell are listed in the market book to the right of the graph.

Offers to buy a share are indicated by a GREEN dot on the graph.

Offers to sell a share are indicated by an ORANGE dot on the graph.

Once a trade is actually made, a BLACK dot will indicate the transaction price.

In the section of the screen labeled "Orders," you can enter new offers to buy or sell shares, or accept existing offers to buy or sell shares.

To buy or sell shares, use the appropriate "Submit New Order" box.

Suppose you want to buy a share for 200. Your offer must be more than the highest existing offer to buy. Type "200" in the appropriate box, then click "buy." The order immediately appears in the market book and on the graph. 
Suppose you want to sell a share for 350 . Your offer must be less than the lowest existing offer to sell. Type "350" in the appropriate box, then click "sell." The order immediately appears in the market book and on the graph.

If you want to cancel your offer to buy or sell a share, click on the appropriate button in the section labeled "Cancel Orders." This removes the offer from the market.

Your outstanding offers to sell cannot exceed the number of shares you own. Your offers to buy cannot exceed your cash on hand. Therefore, you may need to cancel an existing offer before you enter a new one.

To accept an outstanding offer to buy or sell, use the boxes labeled "Immediate Order." This section of the screen shows the best price available to buy or sell.

Suppose you decide to buy at 350. When you click on "buy," your shares increase by 1 and your cash decreases by 350 .

Instead, suppose you decide to sell at 200. When you click on "sell" your shares decrease by 1 and your cash increases by 200.

The lower right-hand section of the screen is labeled "Information."

During a round, this section will show (1) the possible dividend amounts, and (2) the average remaining dividend amount. 


\section{Financial Report}

At the end of each round, the information section will present a financial report.

You will be given a moment after each round to review this report.

[NO LOAN + Fundamental Value Treatment]
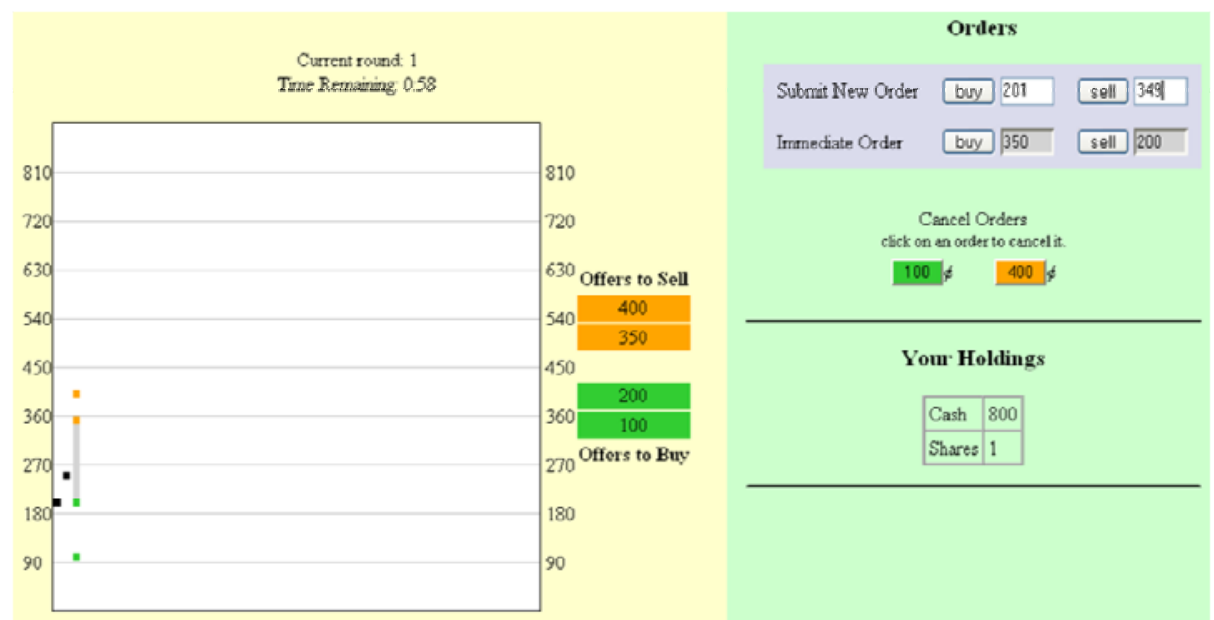
The financial report displayed at the end of each round will show the following:

(1) Your current cash balance, including any dividends earned at the end of the round.

(2) The value of your shares. This is determined by multiplying the number of shares held times the number of rounds remaining times the average dividend - in this case, the share value is $336 c$ (1 share $\times 14$ rounds $\times 24$ c).

(3) The total value of your cash and shares and your net worth, which is the sum of your cash and share value.

(4) The total amount of dividends added to cash - equal to the number of shares held times the dividend per share.

\begin{tabular}{|l|c|}
\hline Cash Balance & 828 \\
\hline Value of shares held & 336 \\
\hline Total (Cash + Shares) & 1164 \\
\hline Net Worth & 1164 \\
\hline Total dividend added to cash & 28 \\
\hline
\end{tabular}

\begin{tabular}{|c|c|c|}
\hline Example & Cash & Shares \\
\hline $\begin{array}{l}\text { Suppose Joe begins round } 6 \text { with } 1000 \text { in cash } \\
\text { and } 2 \text { shares. }\end{array}$ & 1000 & 2 \\
\hline $\begin{array}{l}\text { He decides to buy } 1 \text { share at a price of } 200 \text {. His } \\
\text { cash goes down by } 200 \text { and his shares increase } \\
\text { to } 3 \text {. }\end{array}$ & 800 & 3 \\
\hline $\begin{array}{l}\text { Next he buys another share for } 200 \text {. The } \\
\text { number of shares goes up by } 1 \text { and his cash } \\
\text { decreases by } 200 \text {. }\end{array}$ & 600 & 4 \\
\hline $\begin{array}{l}\text { Then Joe decides to sell a share for } 300 . \text { His } \\
\text { cash increases and his shares decrease. }\end{array}$ & 900 & 3 \\
\hline $\begin{array}{l}\text { At the end of the round, the dividend is } 28 c \text { per } \\
\text { share }(3 \times 28=84) \text {. }\end{array}$ & 984 & 3 \\
\hline
\end{tabular}

Now let's look at Joe's financial report at the end of round 6 .

His cash is $984 \mathrm{c}$.

He has 3 shares valued at $216 c$ each (9 rounds remaining $\times 24 c$ ). 
His total value and net worth are $1632 c(984 c+648 c)$

The total dividend amount in round 6 is $84 c(3 \times 28 c)$.

Joe's cash balance of $984 \mathrm{C}$ and his 3 shares will carry over to the beginning of round 7.

\begin{tabular}{|l|r|}
\hline Cash Balance & 984 \\
\hline Value of shares held & 648 \\
\hline Total (Cash + Shares) & 1632 \\
\hline Net Worth & 1632 \\
\hline Total dividend added to cash & 84 \\
\hline
\end{tabular}

[NO LOAN + Historical Cost Treatment]

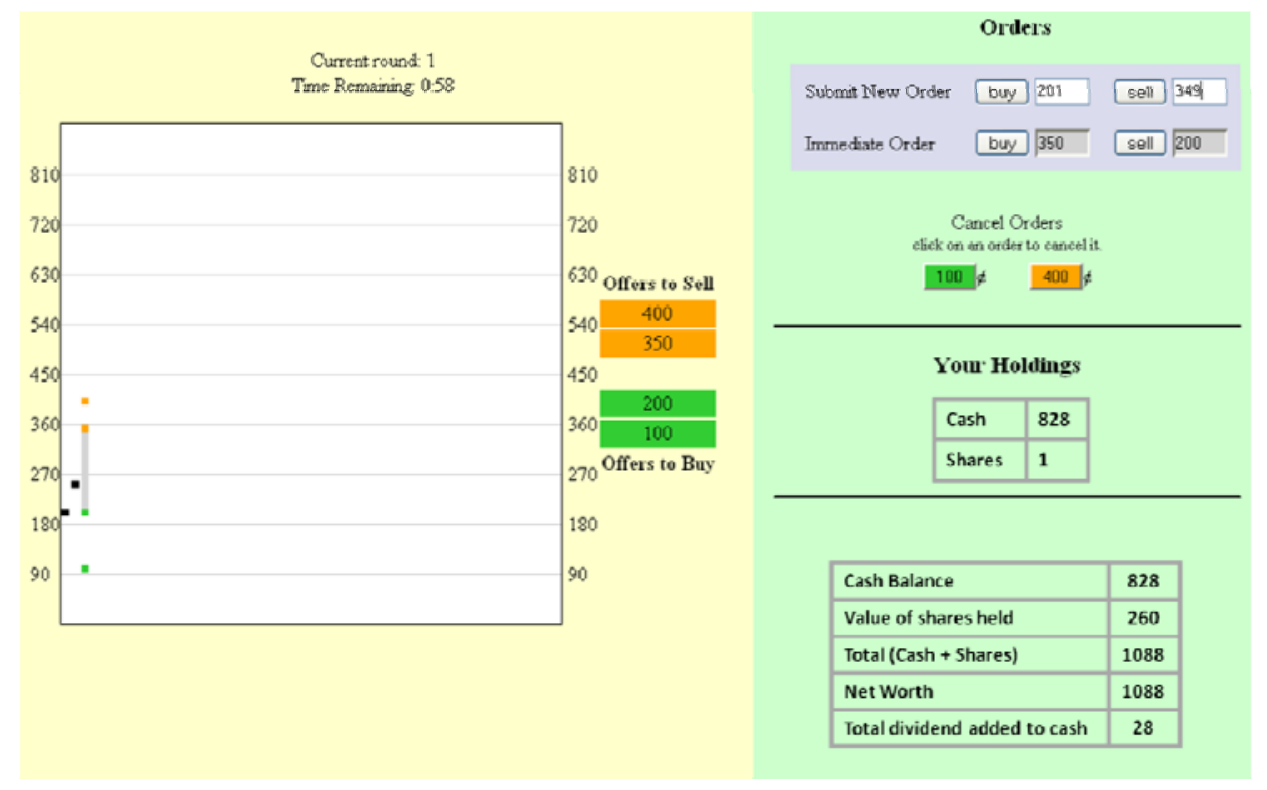

The financial report displayed at the end of each round will show the following:

(1) Your current cash balance, including any dividends earned at the end of the round.

(2) The value of your shares. This is the amount paid for the shares - in this case, the one share was purchased for 260 cents. 
(3) The total value of your cash and shares and your net worth, which is the sum of your cash and share value.

(4) The total amount of dividends added to cash - equal to the number of shares held times the dividend per share.

\begin{tabular}{|l|c|}
\hline Cash Balance & 828 \\
\hline Value of shares held & 260 \\
\hline Total (Cash + Shares) & 1088 \\
\hline Net Worth & 1088 \\
\hline Total dividend added to cash & 28 \\
\hline
\end{tabular}

\begin{tabular}{|c|c|c|}
\hline Example & Cash & Shares \\
\hline $\begin{array}{l}\text { Suppose Joe begins round } 6 \text { with } 1000 \text { in cash } \\
\text { and } 2 \text { shares. }\end{array}$ & 1000 & 2 \\
\hline $\begin{array}{l}\text { He decides to buy } 1 \text { share at a price of } 200 \text {. His } \\
\text { cash goes down by } 200 \text { and his shares increase } \\
\text { to } 3 \text {. }\end{array}$ & 800 & 3 \\
\hline $\begin{array}{l}\text { Next he buys another share for } 200 \text {. The } \\
\text { number of shares goes up by } 1 \text { and his cash } \\
\text { decreases by } 200 \text {. }\end{array}$ & 600 & 4 \\
\hline $\begin{array}{l}\text { Then Joe decides to sell a share for } 300 \text {. His } \\
\text { cash increases and his shares decrease. }\end{array}$ & 900 & 3 \\
\hline $\begin{array}{l}\text { At the end of the round, the dividend is } 28 c \text { per } \\
\text { share }(3 \times 28=84) \text {. }\end{array}$ & 984 & 3 \\
\hline
\end{tabular}

Now let's look at Joe's financial report at the end of round 6.

His cash is 984 c.

He has 3 shares; one valued at $250 c$ and two valued at $200 c$ each (the purchase price of each share).

His total value and net worth are $1634 c(984 c+650 c)$.

The total dividend amount in round 6 is $84 c(3 \times 28 c)$.

Joe's cash balance of $984 \mathrm{C}$ and his 3 shares will carry over to the beginning of round 7. 


\begin{tabular}{|l|r|}
\hline Cash Balance & 984 \\
\hline Value of shares held & 650 \\
\hline Total (Cash + Shares) & 1634 \\
\hline Net Worth & 1634 \\
\hline Total dividend added to cash & 84 \\
\hline
\end{tabular}

[NO LOAN + Mark-to-Market Treatment]

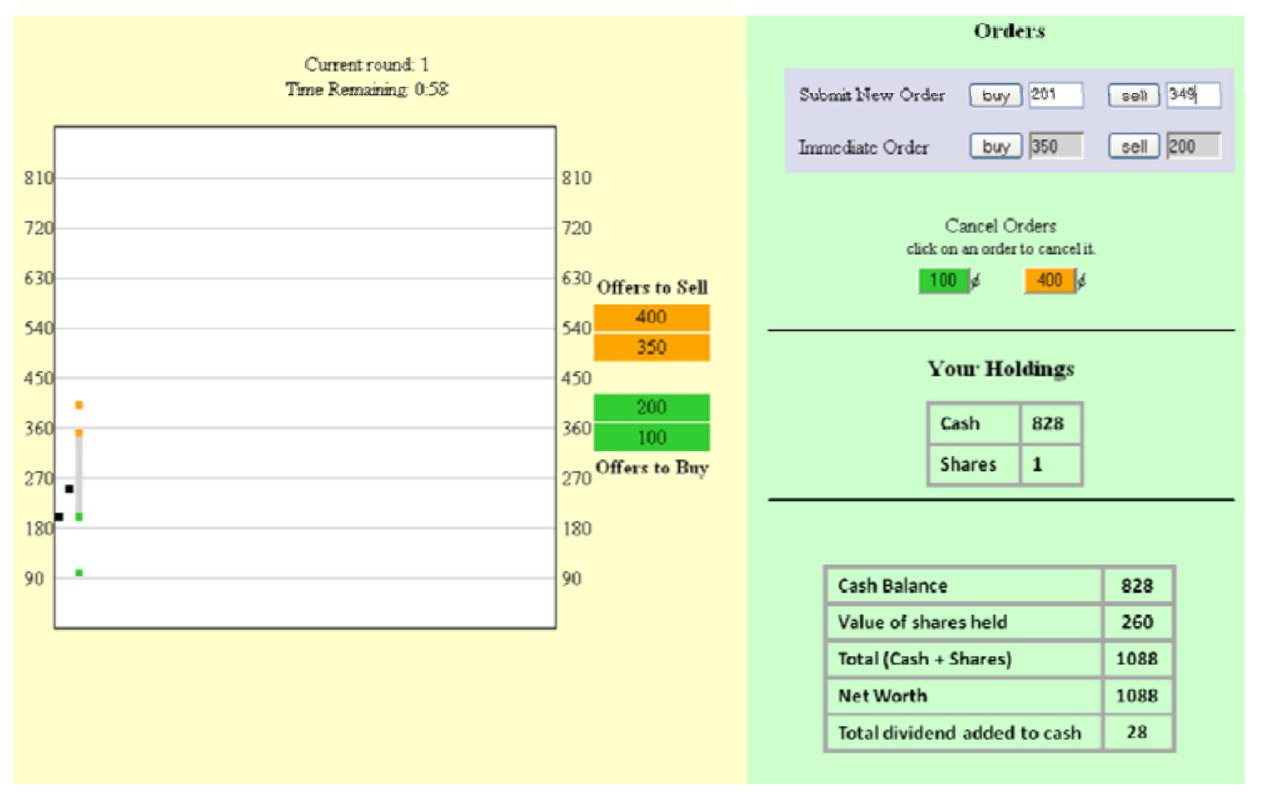

The financial report displayed at the end of each round will show the following:

(1) Your current cash balance, including any dividends earned at the end of the round.

(2) The value of your shares. This is determined by multiplying the number of shares held by the last price at which a share traded in the market - in this case, the last trade was at 260 cents.

(3) The total value of your cash and shares and your net worth, which is the sum of your cash and share value.

(4) The total amount of dividends added to cash - equal to the number of shares held times the dividend per share. 


\begin{tabular}{|l|c|}
\hline Cash Balance & 828 \\
\hline Value of shares held & 260 \\
\hline Total (Cash + Shares) & 1088 \\
\hline Net Worth & 1088 \\
\hline Total dividend added to cash & 28 \\
\hline
\end{tabular}

\begin{tabular}{lcc} 
Example & Cash & Shares \\
\hline $\begin{array}{l}\text { Suppose Joe begins round } 6 \text { with } 1000 \text { in cash } \\
\text { and } 2 \text { shares. }\end{array}$ & 1000 & 2 \\
$\begin{array}{l}\text { He decides to buy } 1 \text { share at a price of } 200 . \text { His } \\
\text { cash goes down by } 200 \text { and his shares increase }\end{array}$ & 800 & 3 \\
to 3. & \\
Next he buys another share for 200. The \\
number of shares goes up by 1 and his cash \\
$\begin{array}{l}\text { decreases by } 200 . \\
\begin{array}{l}\text { Then Joe decides to sell a share for } 300 . \text { His } \\
\text { cash increases and his shares decrease. }\end{array}\end{array}$ \\
$\begin{array}{l}\text { At the end of the round, the dividend is } 28 \text { c per } \\
\text { share (3x28=84). }\end{array}$ & 900 \\
\end{tabular}

Now let's look at Joe's financial report at the end of round 6 .

His cash is $984 \mathrm{c}$.

He has 3 shares valued at 300 each (the price of the last trade).

His total value and net worth are $1884 c(984 c+900 c)$

The total dividend amount in round 6 is $84 c(3 \times 28 c)$.

Joe's cash balance of $984 c$ and his 3 shares will carry over to the beginning of round 7. 


\begin{tabular}{|l|r|}
\hline Cash Balance & 984 \\
\hline Value of shares held & 900 \\
\hline Total (Cash + Shares) & 1884 \\
\hline Net Worth & 1884 \\
\hline Total dividend added to cash & 84 \\
\hline
\end{tabular}

[LOAN + Fundamental Value Treatment]
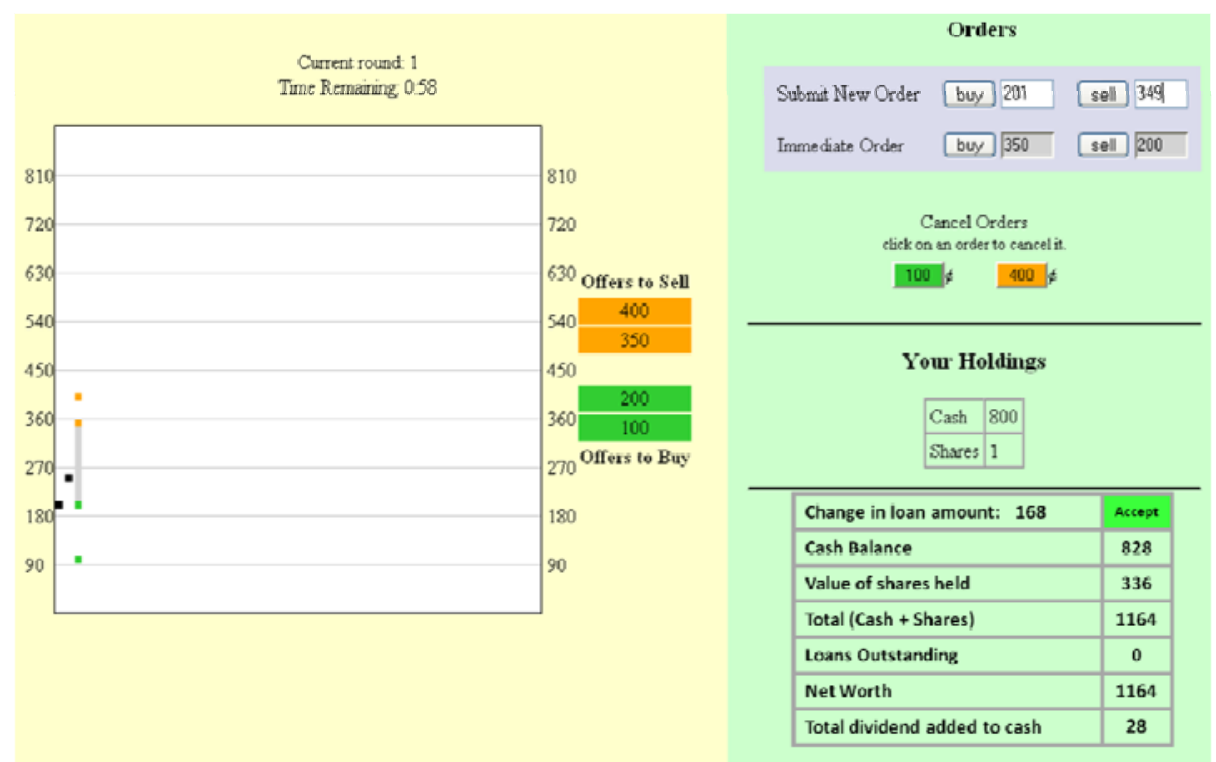

The financial report displayed at the end of each round will show the following:

(1) Your cash balance, including any dividends paid this round.

(2) The value of your shares. This is the number of shares held times the average dividend for the remaining rounds - in this case, 1 share $\times 14$ rounds $\times 24 c=336 c$.

(3) The total value (sum) of your cash and shares.

(4) Your loans outstanding.

(5) Your net worth, which is your total cash and shares, less your outstanding loans. 
(6) The total amount of dividends added to cash - equal to the number of shares held times the dividend per share.

\begin{tabular}{|l|c|}
\hline Change in Loan Amount: 168 & Accept \\
\hline Cash Balance & 828 \\
\hline Value of shares held & 336 \\
\hline Total (Cash + Shares) & 1164 \\
\hline Loans Outstanding & 0 \\
\hline Net Worth & 1164 \\
\hline Total dividend added to cash & 28 \\
\hline
\end{tabular}

The top line in the financial report shows the "Change in Loan Amount."

This amount is the amount of cash that you are allowed to borrow.

To accept this loan amount, click on the green button labeled "Accept."

If you decide to accept the loan, the loan amount will be added to your cash account. (The financial report is not updated until the next round.) The cash can then be used to buy additional shares in subsequent rounds.

If the share value decreases and your loan amount exceeds $50 \%$, the loan amount will be reduced (partially repaid).

When the loan amount is reduced, the loan repayment is deducted from your cash.

In this example, the participant had 330 in loans outstanding. However, his share value is only $260 c$, which limits his loans to $130 c(50 \% \times 260 c)$. Thus, $200 c(330 c-130 c)$ has been deducted from the loans outstanding and from cash. 


\begin{tabular}{|l|c|}
\hline Loan Amount Reduced & 200 \\
\hline Cash Balance & 628 \\
\hline Value of shares held & 260 \\
\hline Total (Cash + Shares) & 888 \\
\hline Loans Outstanding & 130 \\
\hline Net Worth & 758 \\
\hline Total dividend added to cash & 28 \\
\hline
\end{tabular}

\begin{tabular}{|c|c|c|}
\hline Example & Cash & Shares \\
\hline $\begin{array}{l}\text { Suppose Joe begins round } 6 \text { with } 1000 \text { in cash } \\
\text { and } 2 \text { shares. }\end{array}$ & 1000 & 2 \\
\hline $\begin{array}{l}\text { He decides to buy } 1 \text { share at a price of } 200 \text {. His } \\
\text { cash goes down by } 200 \text { and his shares increase } \\
\text { to } 3 \text {. }\end{array}$ & 800 & 3 \\
\hline $\begin{array}{l}\text { Next he buys another share for } 200 \text {. The } \\
\text { number of shares goes up by } 1 \text { and his cash } \\
\text { decreases by } 200 \text {. }\end{array}$ & 600 & 4 \\
\hline $\begin{array}{l}\text { Then Joe decides to sell a share for } 300 . \text { His } \\
\text { cash increases and his shares decrease. }\end{array}$ & 900 & 3 \\
\hline $\begin{array}{l}\text { At the end of the round, the dividend is } 28 c \text { per } \\
\text { share }(3 \times 28=84) \text {. }\end{array}$ & 984 & 3 \\
\hline
\end{tabular}

Now let's look at Joe's financial report at the end of round 6.

His cash balance is 984 .

He has 3 shares valued at $216 c$ each ( 3 shares $\times 9$ rounds remaining $\times 24 c=648 c$ ).

His total of cash and shares is $1632 c(984 c+648 c)$.

His loan outstanding is currently $200 c$. However, Joe could borrow up to $324 c$. So the change in loan amount is $124 \mathrm{c}$. If Joe accepts the loan, $124 \mathrm{C}$ will be added to his cash account. 
Joe's net worth is $1432 c(1632 \zeta-200 c)$ and the total dividend amount in round 6 is $84 c(3 \times 28 c)$.

Joe's cash balance of 984C, plus an additional 124c if he accepts the loan, will carry over to round 7 , along with his 3 shares.

\begin{tabular}{|l|r|}
\hline Change in loan amount: 124 & Accept \\
\hline Cash Balance & 984 \\
\hline Value of shares held & 648 \\
\hline Total (Cash + Shares) & 1632 \\
\hline Loans Outstanding & 200 \\
\hline Net Worth & 1432 \\
\hline Total dividend added to cash & 84 \\
\hline
\end{tabular}

[LOAN + Historical Cost Treatment]
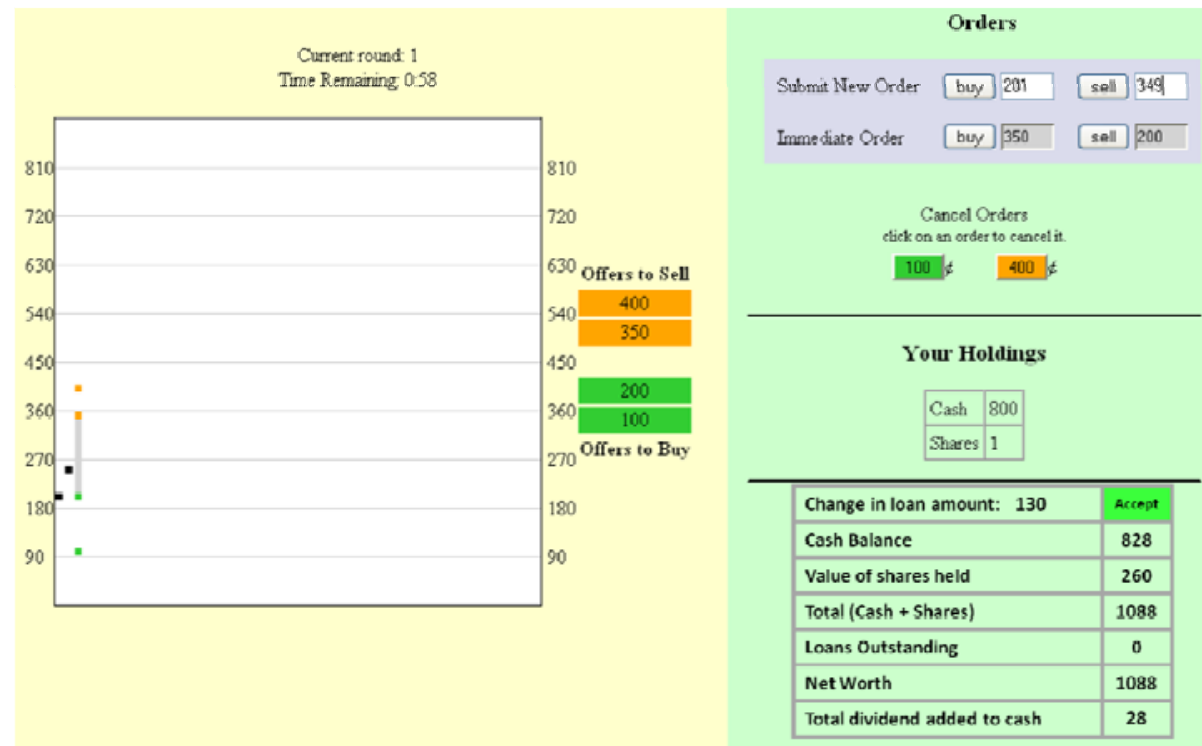

The financial report displayed at the end of each round will show the following:

(1) Your cash balance, including any dividends paid this round.

(2) The value of your shares. This is equal to the price at which the shares were purchased - in this case, $260 c$. 
(3) The total value (sum) of your cash and shares.

(4) Your loans outstanding.

(5) Your net worth, which is your total cash and shares, less your outstanding loans.

(6) The total amount of dividends added to cash - equal to the number of shares held times the dividend per share.

\begin{tabular}{|l|c|}
\hline Change in Loan Amount: 130 & Accept \\
\hline Cash Balance & 828 \\
\hline Value of shares held & 260 \\
\hline Total (Cash + Shares) & 1088 \\
\hline Loans Outstanding & 0 \\
\hline Net Worth & 1088 \\
\hline Total dividend added to cash & 28 \\
\hline
\end{tabular}

The top line in the financial report shows the "Change in Loan Amount."

This amount is the amount of cash that you are allowed to borrow.

To accept this loan amount, click on the green button labeled "Accept."

If you decide to accept the loan, the loan amount will be added to your cash account. (The financial report is not updated until the next round.) The cash can then be used to buy additional shares in subsequent rounds.

If the share value decreases and your loan amount exceeds $50 \%$, the loan amount will be reduced (partially repaid).

When the loan amount is reduced, the loan repayment is deducted from your cash.

In this example, the participant had 330 in loans outstanding. However, his share value is only $260 c$, which limits his loans to $130 c(50 \% \times 260 c)$. Thus, $200 c(330 c-130 c)$ has been deducted from the loans outstanding and from cash. 


\begin{tabular}{|l|c|}
\hline Loan Amount Reduced & 200 \\
\hline Cash Balance & 628 \\
\hline Value of shares held & 260 \\
\hline Total (Cash + Shares) & 888 \\
\hline Loans Outstanding & 130 \\
\hline Net Worth & 758 \\
\hline Total dividend added to cash & 28 \\
\hline
\end{tabular}

\begin{tabular}{|c|c|c|}
\hline Example & Cash & Shares \\
\hline $\begin{array}{l}\text { Suppose Joe begins round } 6 \text { with } 1000 \text { in cash } \\
\text { and } 2 \text { shares. }\end{array}$ & 1000 & 2 \\
\hline $\begin{array}{l}\text { He decides to buy } 1 \text { share at a price of } 200 \text {. His } \\
\text { cash goes down by } 200 \text { and his shares increase } \\
\text { to } 3 \text {. }\end{array}$ & 800 & 3 \\
\hline $\begin{array}{l}\text { Next he buys another share for } 200 \text {. The } \\
\text { number of shares goes up by } 1 \text { and his cash } \\
\text { decreases by } 200 \text {. }\end{array}$ & 600 & 4 \\
\hline $\begin{array}{l}\text { Then Joe decides to sell a share for } 300 . \text { His } \\
\text { cash increases and his shares decrease. }\end{array}$ & 900 & 3 \\
\hline $\begin{array}{l}\text { At the end of the round, the dividend is } 28 c \text { per } \\
\text { share }(3 \times 28=84) \text {. }\end{array}$ & 984 & 3 \\
\hline
\end{tabular}

Now let's look at Joe's financial report at the end of round 6.

His cash balance is 984 .

He has 3 shares -1 share at $250 c$ and 2 at $200 c$ each.

His total of cash and shares is $1634 c(984 c+650 c)$.

His loan outstanding is currently $200 c$. However, Joe could borrow up to $325 c$. So the change in loan amount is 125 c. If Joe accepts the loan, $125 c$ will be added to his cash account. 
Joe's net worth is $1434 c(1634 c-200 \zeta)$ and the total dividend amount in round 6 is $84 c(3 \times 28 c)$.

Joe's cash balance of 984C, plus an additional 125 c if he accepts the loan, will carry over to round 7 , along with his 3 shares.

\begin{tabular}{|l|r|}
\hline Change in loan amount: 125 & Accept \\
\hline Cash Balance & 984 \\
\hline Value of shares held & 650 \\
\hline Total (Cash + Shares) & 1634 \\
\hline Loans Outstanding & 200 \\
\hline Net Worth & 1434 \\
\hline Total dividend added to cash & 84 \\
\hline
\end{tabular}

[LOAN + Mark-to-Market Treatment]
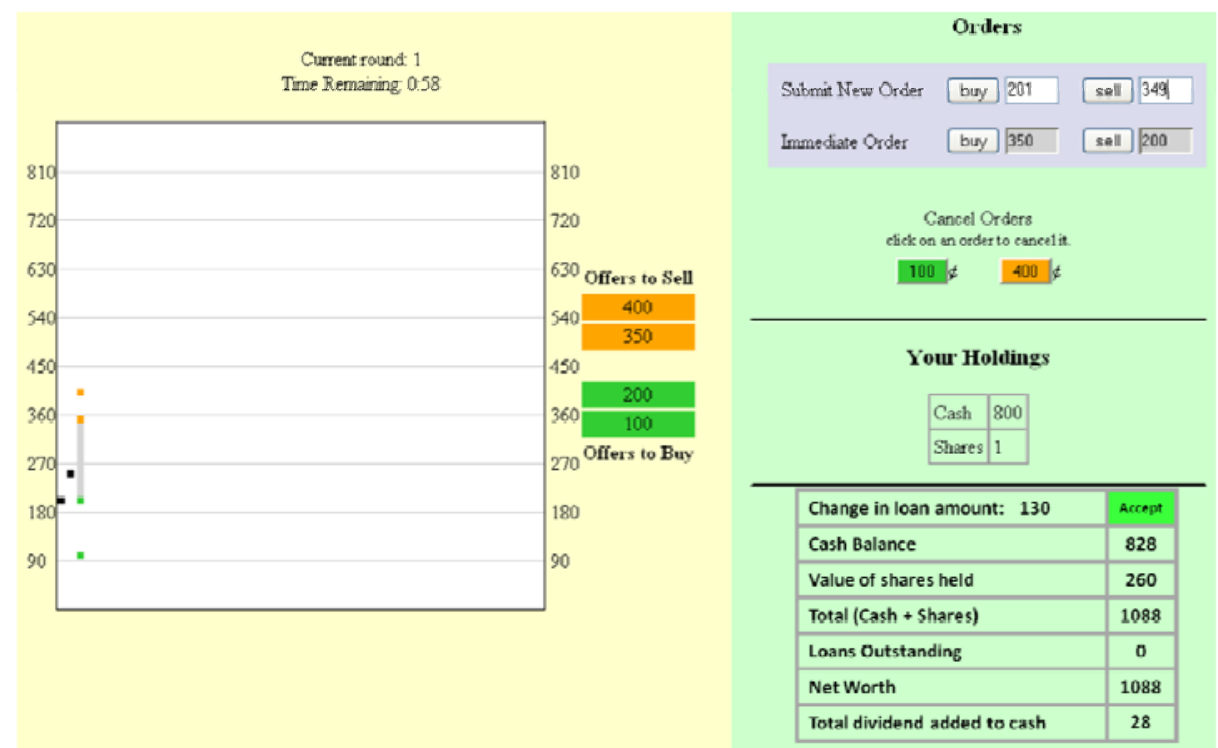

The financial report displayed at the end of each round will show the following:

(1) Your cash balance, including any dividends paid this round.

(2) The value of your shares. This is the number of shares held times the last price at which a share traded in the market - in this case, the last trade was at 260 cents. 
(3) The total value (sum) of your cash and shares.

(4) Your loans outstanding.

(5) Your net worth, which is your total cash and shares, less your outstanding loans.

(6) The total amount of dividends added to cash - equal to the number of shares held times the dividend per share.

\begin{tabular}{|l|c|}
\hline Change in Loan Amount: 130 & Accept \\
\hline Cash Balance & 828 \\
\hline Value of shares held & 260 \\
\hline Total (Cash + Shares) & 1088 \\
\hline Loans Outstanding & 0 \\
\hline Net Worth & 1088 \\
\hline Total dividend added to cash & 28 \\
\hline
\end{tabular}

The top line in the financial report shows the "Change in Loan Amount."

This amount is the amount of cash that you are allowed to borrow.

To accept this loan amount, click on the green button labeled "Accept."

If you decide to accept the loan, the loan amount will be added to your cash account. (The financial report is not updated until the next round.) The cash can then be used to buy additional shares in subsequent rounds.

If the share value decreases and your loan amount exceeds 50\%, the loan amount will be reduced (partially repaid).

When the loan amount is reduced, the loan repayment is deducted from your cash.

In this example, the participant had 330 in loans outstanding. However, his share value is only $260 c$, which limits his loans to $130 c(50 \% \times 260 c)$. Thus, $200 c(330 c-130 c)$ has been deducted from the loans outstanding and from cash. 


\begin{tabular}{|l|c|}
\hline Loan Amount Reduced & 200 \\
\hline Cash Balance & 628 \\
\hline Value of shares held & 260 \\
\hline Total (Cash + Shares) & 888 \\
\hline Loans Outstanding & 130 \\
\hline Net Worth & 758 \\
\hline Total dividend added to cash & 28 \\
\hline
\end{tabular}

\begin{tabular}{|c|c|c|}
\hline Example & Cash & Shares \\
\hline $\begin{array}{l}\text { Suppose Joe begins round } 6 \text { with } 1000 \text { in cash } \\
\text { and } 2 \text { shares. }\end{array}$ & 1000 & 2 \\
\hline $\begin{array}{l}\text { He decides to buy } 1 \text { share at a price of } 200 \text {. His } \\
\text { cash goes down by } 200 \text { and his shares increase } \\
\text { to } 3 \text {. }\end{array}$ & 800 & 3 \\
\hline $\begin{array}{l}\text { Next he buys another share for } 200 \text {. The } \\
\text { number of shares goes up by } 1 \text { and his cash } \\
\text { decreases by } 200 \text {. }\end{array}$ & 600 & 4 \\
\hline $\begin{array}{l}\text { Then Joe decides to sell a share for } 300 . \text { His } \\
\text { cash increases and his shares decrease. }\end{array}$ & 900 & 3 \\
\hline $\begin{array}{l}\text { At the end of the round, the dividend is } 28 c \text { per } \\
\text { share }(3 \times 28=84) \text {. }\end{array}$ & 984 & 3 \\
\hline
\end{tabular}

Now let's look at Joe's financial report at the end of round 6.

His cash balance is 984 .

He has 3 shares valued at 300 each (the price of the last trade).

His total of cash and shares is $1884 c(984 c+900 c)$.

His loans outstanding is currently $300 c$. However, Joe could borrow up to $450 c$. So the change in loan amount is $150 c$. If Joe accepts the loan, $150 c$ will be added to his cash account. 
Joe's net worth is $1584 c(1884 c-300 \zeta)$ and the total dividend amount in round 6 is $84 c(3 \times 28 c)$.

Joe's cash balance of 984c, plus an additional 150 c if he accepts the loan, will carry over to round 7 , along with his 3 shares.

\begin{tabular}{|l|r|}
\hline Change in loan amount: 150 & Accept \\
\hline Cash Balance & 984 \\
\hline Value of shares held & 900 \\
\hline Total (Cash + Shares) & 1884 \\
\hline Loans Outstanding & 300 \\
\hline Net Worth & 1584 \\
\hline Total dividend added to cash & 84 \\
\hline
\end{tabular}




\section{Summary}

\section{[NO LOAN Treatments]}

1. You will be given an initial amount of cash and shares.

2. During each round you can submit offers to buy or sell shares. You trade shares by buying at the lowest offer to sell or by selling at the highest offer to buy. Your cash and shares carry over from one round to the next.

3. Each share pays a dividend of either $0,8,28$, or 60 cents at the end of each round. Each dividend amount is equally likely. The average dividend is $24 c$ per share.

4. The market lasts for fifteen 3-minute rounds. At the end of round 15, the shares will pay one last dividend and then expire. You will be paid based on your final cash balance.

5. A report on your financial status, detailing your cash balance and your share value, will appear at the end of each trading round.

A short quiz follows. After that, we will have a practice round so that you can become familiar with the trading program.

\section{[LOAN Treatments]}

1. You will be given an initial amount of cash and shares.

2. During each round you can submit offers to buy or sell shares. You trade shares by buying at the lowest offer to sell or by selling at the highest offer to buy. Your cash and shares carry over from one round to the next.

3. Each share pays a dividend of either $0,8,28$, or 60 cents at the end of each round. Each dividend amount is equally likely. The average dividend is $24 c$ per share.

4. The market lasts for fifteen rounds. At the end of round 15, the shares will pay one last dividend and then expire. You will be paid based on your final cash balance.

5. You may borrow up to $50 \%$ of the value of your shares at the end of each round. All loans must be repaid at the end if the $13^{\text {th }}$ round.

6. A report on your financial status, detailing your cash balance, your share value, and your loans outstanding will appear at the end of each trading round.

A short quiz follows. After that, we will have a practice round so that you can become familiar with the trading program. 


\section{Quizzes}

[Questions for both No Loan and Loan Treatments]

(1) How many dividend payments would a share pay out in the experiment? (Answer: 15.)

(2) True or False? Your net worth at the end of a round is your cash plus the value of shares you have on hand minus your loan. (Answer: True.)

(3) What is the average dividend payout per round per share? (Answer: 24 cents.)

(4) How much would a share be worth when the market is closed at the end of round 15? (Answer: Zero.)

(5) The value of each share you held reported in the financial statement at the end of a round is determined by? (Answer: Average Remaining Dividends (in M2F) or Purchase Cost (in $\mathrm{HC}$ ) or the last transaction price of the round (in M2M))

(6) Your earnings from the experiment will be _? (Answer: Your final cash on hand.)

[Additional Questions for Loan Treatments]

(1) Your loan can never exceed what _\% of your net worth? (Answer: 50.)

(2) Suppose at the end of a period your loan outstanding was 600. Your net worth was 2800. How much can your loan be increased by? (Answer: 800.)

(3) Suppose at the end of a period your loan was 600 . Your net worth was 1000 , how much of the loan must be paid down? (Answer: 100.)

(4) At the end of which round should loans be paid down completely? (Answer: 13.)

(5) True or False? If you do have not have enough cash on hand to cover the required loan reduction, your shares will be taken into custody and auctioned off at whatever prices available in the market. (Answer: True.) 